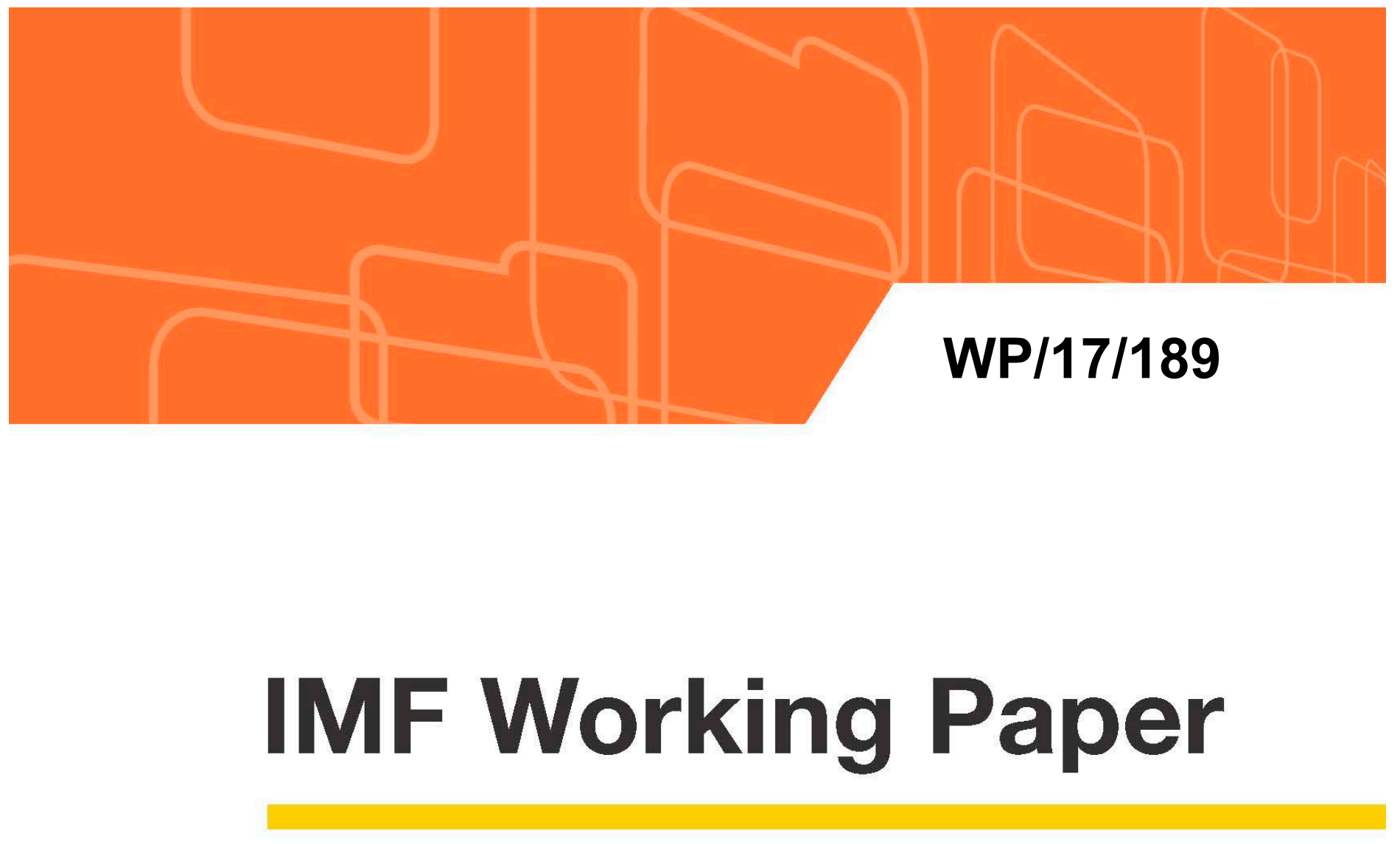

\title{
Finance and Employment in Developing Countries: The Working Capital Channel
}

by Mai Chi Dao and Lucy Qian Liu

IMF Working Papers describe research in progress by the author(s) and are published to elicit comments and to encourage debate. The views expressed in IMF Working Papers are those of the author(s) and do not necessarily represent the views of the IMF, its Executive Board, or IMF management.

$$
\text { I N TER N A T | O N A L M O N E T A R Y F U N D }
$$




\title{
IMF Working Paper
}

Research Department

\section{Finance and Employment in Developing Countries: The Working Capital Channel Prepared by Mai Chi Dao and Lucy Qian Liu ${ }^{1}$}

Authorized for distribution by Luis Cubeddu and Maria Soledad Martinez Peria

August 2017

\section{IMF Working Papers describe research in progress by the author(s) and are published to elicit comments and to encourage debate. The views expressed in IMF Working Papers are those of the author(s) and do not necessarily represent the views of the IMF, its Executive Board, or IMF management.}

\begin{abstract}
We study the effect of external financing constraint on job creation in emerging markets and developing countries (EMDC) at the firm level by looking at a specific transmission channel - the working capital channel. We develop a simple model to illustrate how the need for working capital financing of a firm affects the link between financial constraint and the firm's job creation. We show that the effect of relaxing financial constraint on job creation is greater the smaller the firm scale and the more labor-intensive its production structure. We use the World Bank Enterprise Surveys data to test the main predictions of the model, and find strong evidence for the working capital channel of external finance on firm employment.
\end{abstract}

JEL Classification Numbers: D22, D24, G20, J21, J23

Keywords: Financial constraint, firm-level employment, job creation, working capital financing

Author's E-Mail Address: mdao@,imf.org, qliu3@imf.org

\footnotetext{
${ }^{1}$ We would like to thank Jorge Alvarez, Meghana Ayyagari, Philippe Bacchetta, Luis Cubeddu, Sebnem Kalemli-Ozcan, Luc Laeven, Camelia Minoiu, Maria Soledad Martinez Peria, and Sangeetha Pratap for helpful comments and suggestions.
} 


\section{Table of Contents}

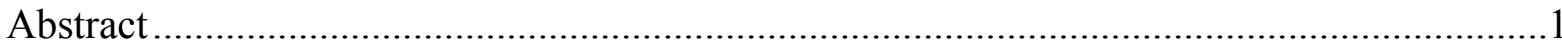

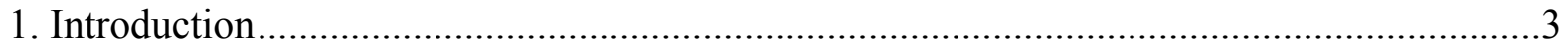

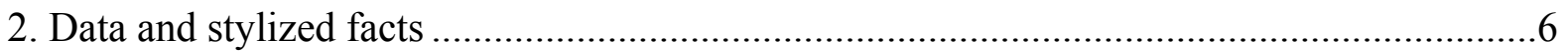

3. A simple model of working capital financing........................................................

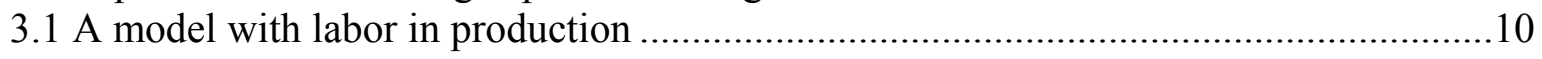

3.2 A model with both labor and capital in production ..............................................13

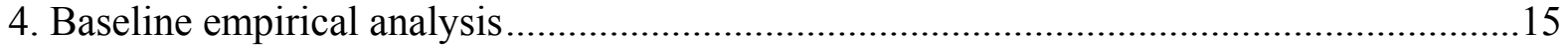

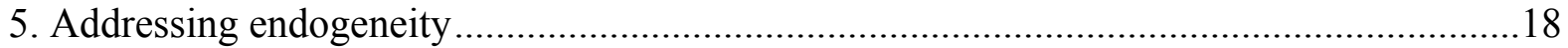

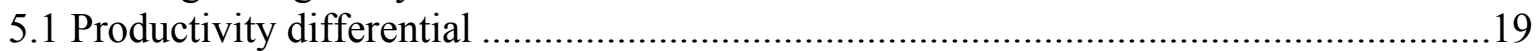

5.2 Estimation with firm panel .................................................................................20

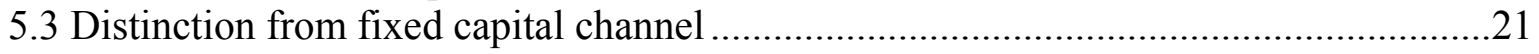

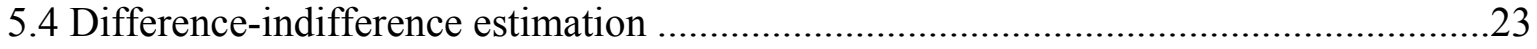

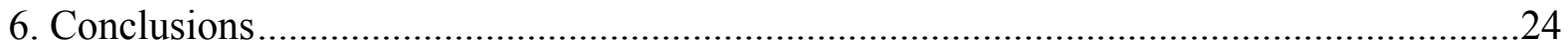

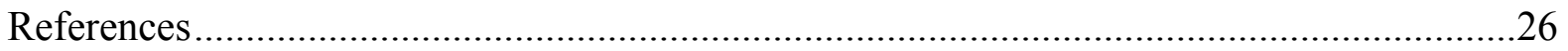

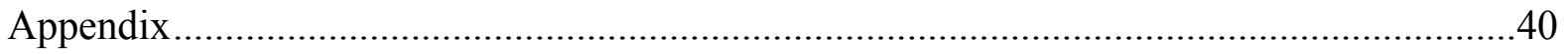

Figures

1. Share of working capital financed externally by industry .........................................29

2. Share of working capital financed externally: actual vs. predicted ..................................30

3. Distribution of labor cost share in working capital by firm size....................................

4. Contribution to employment and job creation by firm size ..........................................32

5. Correlation between aggregate employment growth and degree of financial constraint for

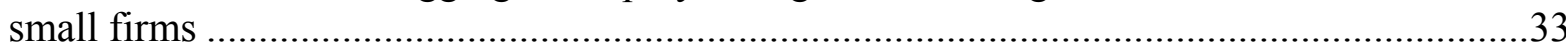

Tables

1. Access to finance and firm-level employment: within industry-country-year valuation.....34

2. Access to finance and firm-level employment: differential impact within industry-country-

year

3. Access to finance and ex-post productivity: differential impact within industry-country-

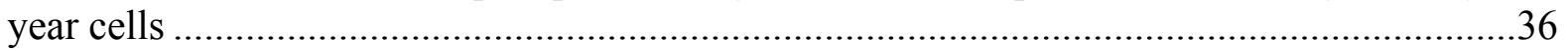

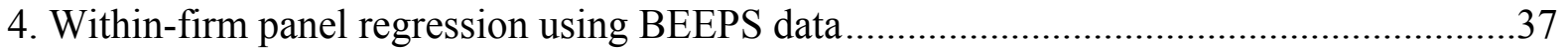

5. Working capital versus fixed capital financing channel ............................................. 38

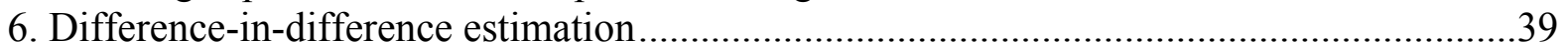




\section{Introduction}

The link between financial development and economic growth has been extensively studied in the literature. There is a broad consensus that financial development tends to increase economic growth by allowing better access to capital and improving the efficiency of capital allocation (Beck and Levine, 2004[8]; Levine, 2005[21]; and Sahay et al. 2015[27]) 1 tween financial development and employment is less clear. While better access to finance may allow firms to hire more labor, it also encourages firms to invest in more capital, which may not automatically translate into greater job creation. In the case where firms have a production technology with capital and labor being substitutable, an increase in capital investment may reduce firms' labor demand, lowering job creation. The net effect, therefore, depends on firm characteristics and production structure.

In particular, firm sizes could play an important role in determining the finance-employment relationship. Empirical studies have found that firms with different sizes may face different operational and institutional constraints. Specifically, small and medium-size enterprises (SMEs) tend to be more adversely affected by financial, institutional, and legal obstacles (Beck et al., 2005[7]). Among them, financing constraints are often found to have the largest negative impact on firm growth, more so in countries with underdeveloped financial systems. Given that small firms also tend to be more labor-intensive than large firms (Oi, 1983[24] and Garmaise, 2008[16]), one would expect that the finance-employment relationship is stronger for small firms than that for large firms. Indeed, a recent paper by Ayyagari et al. (2016)[3] shows that increased supply of credit results in higher employment growth especially among small firms in developing countries.

Despite the empirical evidence described above, the precise mechanism through which the finance-employment linkage varies with firm size has not yet been systematically explored. Our paper aims to fill this gap. By exploring a specific channel—namely the need to finance working capital with external credit, our paper examines how variability in external financing affects firm employment growth, and how this finance-employment relation varies with firm characteristics. Following the standard definition in the literature, working capital here refers to a firm's operating

\footnotetext{
${ }^{1}$ Some recent studies suggest that the relationship between financial development and growth could be nonlinear: the positive effect of financial development is only up to a certain level, beyond which financial development could hurt growth. See Arcand et al. (2012) [1] and Cecchetti and Kharroubi (2015)[13] for example.
} 
liquidity, which covers the expenses of payrolls and part of fixed capital spending.

Our paper contributes to the literature on finance and employment both theoretically and empirically. First, we develop a simple model which can be easily extended to a general setup to illustrate the mechanism behind the working capital channel. Following Bacchetta et al. (2014)[4], we assume that firms need to finance a portion of their working capital—namely wage bill and capital spending - in advance of production completion. This liquidity need is in part covered by external financing, which implies that access to external finance directly affects the level of firm employment above and beyond its effect through capital. By examining the role of firm characteristics, we show that relaxing financial constraint faced by a firm increases its employment growth, and this effect is larger the smaller the firm, the more labor-intensive its production structure, and the larger its inherent need to finance working capital.

On the empirical front, we contribute to the literature by extending the analysis to a large number of EMDCs, where the issues of financial frictions and job creation are particularly acute. More specifically, we derive and test specific theoretical predictions regarding the effect of financial constraints on job creation at the firm level, and examine how this effect varies with various firm characteristics. In addition, we use survey reports from individual firms to measure the difficulty in obtaining access to finance, as opposed to measures of observed credit usage or other measures of effective credit intensity at the industry or economy level. Our survey-based measure helps alleviate the endogeneity concern embodied in the ex-post measures, as it captures the ex-ante degree of financial constraint faced by the firm. In contrast, the ex-post measures may reflect the compositional effects associated with changes in firm output.

Empirical research using micro data to study heterogeneous firms has been growing over the last decade, partially driven by the increasing availability of firm-level datasets. Using a firmlevel survey database covering 54 countries, Beck et al. (2005)[7] study the effect of financial, legal and corruption problems on firms growth rates. Their findings suggest that small firms are more adversely affected by all types of obstacles in comparison with larger firms. On bank financing for SMEs in particular, Beck (2013)[5] provides a comprehensive survey of the literature. His review concludes that financial deepening can help alleviate financing constraints for SMEs and through this channel reduce poverty and create high-quality jobs. In terms of job creation by SMEs, Haltiwanger et al. (2013)[18] examines how the employment share and job creation rate 
vary across the distribution of firm size in advanced economies, while Ayyagari (2014)[2] studies the same relationship for developing countries.

The effect of financial development on labor markets has received increasing attention in the recent literature, particularly since unemployment has become a major concern for policy makers in the wake of the global financial crisis. Several empirical studies estimate the impact of financial conditions on employment by comparing the labor market conditions before and after financial regulation changes, or before and after a large financial shock. Most of these studies are limited to industrial countries, mainly the US (Mian and Sufi, 2014[22]; Chodorow-Reich, 2014[15]; Haltenhof et. al. 2014[17]; and Benmelech et al., 2011[9]). The paper by Pagano and Pica (2012)[25] studies the financial-employment relation in both advanced and low-income economies. Their empirical analysis using industry-level data finds that the positive relation between financial development and employment growth is only present in middle- and low-income countries but not in OECD countries. Similar to our paper, their study also presents a theoretical model to illustrate how financial development affects employment. In their economy, firms borrow external fund to finance capital investment. Hence, finance affects employment solely through its impact on capital accumulation. In contrast, our model considers firms external liquidity needs to finance both working and investment capital, which presents a more comprehensive framework to study the finance-labor relation.

Our empirical analysis is closely related to the work by Beck et al. (2008) [6] and Ayyagari et al. (2016)[3]. Using industry-level and firm-level data respectively, these papers find that financial development benefits small firms disproportionately more in terms of employment growth than large ones. However, they do not provide any theory to explain the underlying mechanism for such an empirical pattern to hold. The paper by Catao et al. (2009)[12] explores one particular channel for credit to affect formal employment growth. Using Brazilian micro data, they show that financial deepening is associated with lower informality and hence higher formal employment growth.

The concept of labor input, as part of the working capital, requiring financing, has also gained growing attention in recent studies. Bacchetta et al. (2014)[4] explore the implication of this working capital channel for the co-movement of employment and corporate cash holding at business cycle frequency in the US. Chan (2014)[14] introduces working capital into a dynamic model of 
firm investment and shows how this can alter the firm's response to asymmetric profitability shocks compared to a model with fixed capital investment needs only. The paper also tests the model predictions using firm-level data for Bangladesh. The model in our paper is set in a simpler static environment which is nevertheless well-suited to analyze the differential effect of financing constraint on job creation for firms with varying size and labor intensity. Moreover, we test the model predictions using a dataset that arguably covers the most comprehensive set of EMDCs.

The findings of our paper have important policy implications. Evidence from recent empirical research shows that small firms are an important engine for job growth, particularly in EMDCs, as they create more jobs on average and contribute a greater share to the overall employment growth than large firms (see Ayyagari, 2014[2]). Therefore, alleviating financial constraints on small firms could constitute an important part of the job creation strategy in EMDCs. By exploring a particular channel through which finance affects job creation particularly in small, labor-intensive firms, our analysis offers specific policy recommendations on fostering job growth and reducing inequality.

The remainder of this paper is organized as follows. Section 2 describes the firm-level data and presents some stylized facts. Section 3 develops a simple model to illustrate how the presence of working capital financing affect the finance-employment relation. Section 4 summarizes our baseline empirical results and Section 5 discusses various methodologies that are used to address the endogeneity issue. Finally, Section 6 concludes with some policy implications.

\section{Data and stylized facts}

We use data from firm-level surveys conducted by the World Banks Enterprise Surveys (WBES) between 2006 and 2015. These surveys employ a common questionnaire and sampling methodology (stratified random sampling), and aim to be representative at the national level of the nonagricultural private sector of each country. The survey was originally designed to measure the quality and impact of a broad range of business environment characteristics including access to finance, corruption, infrastructure, crime, and competition. As such, firms' perception of various obstacles in these areasisare obtained and quantified in a simple ordinal scale. At the same time, some key measures of firm performance, most importantly sales and employment, are also part of the survey, as well as a host of variables on firm characteristics (ownership structure, product clas- 
sification, export status, etc). The sample in each country consists of formal (registered) companies in manufacturing and services sectors with 5 or more employees, excluding companies with 100 percent public ownership.

A useful feature of this dataset is the sampling design of the survey. The strata forWBES are firm size, business sector, and geographic region within a country. Firm size levels are based on the number of full-time employees. Geographic regions within a country are selected based on which cities/regions collectively contain the majority of economic activity. Coverage of sectors is more granular the larger is the economy and the more heterogeneity is expected within each broad sector. The sampling weights allow us to construct nationally representative samples of the private sector in each country to obtain some key summary statistics.

After cleaning the data to remove missing or invalid observations, we arrive at roughly 62,000 firm-year observations across more than 130 countries surveyed between 2006 and 2015. The overwhelming majority of the countries sampled are low and middle-income countries, with a few advanced European economies. Table B.1 in the Appendix provides a list of countries in the surveys, as well as the number of firms and years of surveys for each country. Note that most countries have had at least two waves of surveys roughly 4 years apart, and a subset of countries in Central and Eastern Europe have had several waves of surveys following a panel of firms. This subset of firm-level panel data will allow us to control for firm-specific unobservable variables in the empirical exercise.

While the traditional view on the real effects of financial frictions focuses on the channel of capital investment, we stress the importance of the working capital financing channel. Indeed, a significant share of working capital held by firms to pay for operating expenses is actually financed externally. Figure 1 shows the average share of working capital financed by external funds at the 2-digit industry level (ISIC Rev 3) across all countries and years, using our WBES survey data. On average across all industries, around 25 percent of working capital is financed externally through bank credit, supplier/trade credit, informal borrowing, or a combination of them. Even for industries that tend to be more labor intensive, such as hotels/restaurants, the average share of working capital financed externally is nontrivial (about 15 percent).

The decision on how much working capital to be financed externally depends on various factors. At the industry level, several structural features inherent in the characteristics of the produc- 
tion process play an important role. For instance, a firm is more likely to finance its operational expenses externally the longer is its production lag (defined as the duration between the beginning of the production until the finished good is ready), the greater is the extent to which the firm produces to stock rather than to order (see Carlson, 1973[11]), and the further upstream it is in the production value chain (see Kalemli-Ozcan et al., 2014[19]). The link between the need of external financing and the position in the production chain can be explained by the fact that, the more upstream in the production chain a firm is located, the longer it takes for the firm to receive the full revenue of its value added, as suppliers often need to finance downstream producers in the production chain by extending trade credits and other types of loans. To illustrate the contribution of these industry characteristics, we regress the average share of externally financed working capital (WKF) from the WBES of 23 manufacturing industries on measures of the industry-specific "upstreamness" (UPS), production length (PL, measured in months) and stock-to-shipment ratio (SS). Using a simple OLS regression, we obtain the following results: ${ }^{2}$

$$
W K F_{i}=13.202+3.837^{* *} \times U P S_{i}+2.875 P L_{i}+72.162^{* *} \times S S_{i}+u_{i}, R^{2}=0.3 .
$$

The measure of upstreamness and the stock-to-shipment ratio are statistically significant at the 5 percent level. Together, the three production-specific features explain about 30 percent of the variation in WKF across industries in all countries. Figure 2 plots the actual versus predicted WKF from the simple regression model in equation (1) and shows the strong positive correlation of the two series.

To the extent that payroll expenses are a major part of working capital, variation in access to external financing can affect a firm's labor demand even for a given level of fixed capital. The magnitude of such an effect presumably depends on the size of the labor share in working capital, which may vary across firms of different sizes. In particular, one would expect that small firms allocate a larger share of their operating expenses to labor cost than large firms. This can be due to production-specific technology (small firms are more prevalent in services industries with lower capital-labor ratio than large firms), but also distortions within an industry, as small firms tend to

\footnotetext{
${ }^{2}$ Industry-specific measure of "upstreamness" is taken from Kalamli-Ozcan et al. (2014)[19], the production length and stock-to-shipment ratio are calculated as in Carlson (1973)[11] using data from the US Annual Survey of Manufacturing in 2013.
} 
have higher overhead costs, or face larger financial constraint and hence have lower capital-labor ratio (e.g. Garmaise, 2008[16]). Of course, small firms are also more financially constrained in their capital investment, so the working capital channel may interact with and add to the financial constraint on fixed capital investment of small firms, as we show in our model.

Figure 3 shows the distribution of the labor share in operating expenses (financed by working capital) across firms of different sizes. Small firms clearly have a greater labor share in working capital than large firms, with the correlation holding up even if we restrict the sample to the manufacturing sector (that is, leaving out the labor intensive services sector), and also when we consider the distribution within each manufacturing industry (that is, abstract from technologydriven labor share). On average, a firm with less than 20 employees has a labor share in working capital that is a third higher than a firm with 100 employees or more. The larger share of labor cost implies that a given change in external financing capability of working capital is likely to affect labor demand in small firms disproportionately more than in large firms.

Finally, we offer some evidence on the contribution of small firms to the overall employment and job growth in an economy, as an illustration on the importance of boosting job creation by small firms. Consistent with the findings in the previous literature, employment in smaller firms (less than 50 employees) in our sample accounts for a much larger share of total employment than that in larger firms (more than 250 employees). See the upper panel of Figure 4 . The role of small firms is even more pronounced when looking at the composition of net employment growth. As the lower panel of Figure 4 shows, over 60 percent of net job creation across EMDCs in the sample is accounted for by firms with less than 50 employees $3^{3}$

\section{A simple model of working capital financing}

This section develops a simple framework to explore the channels through which financial constraint affects firms' decisions on job creation. Motivated by the stylized facts presented in the previous section, we consider an economy where firms need to hold working capital to cover the cost of operation prior to the receipt of revenue, and part of the working capital is financed externally through borrowing. Due to financial frictions, firms can only borrow up to a certain fraction

\footnotetext{
${ }^{3}$ The WBES surveys ask firms to report the number of full-time employees at the end of last fiscal year and 3 fiscal years ago. The net job creation is calculated as the difference between these two numbers.
} 
of its net worth. Thus, the tightness of such a borrowing constraint illustrates the degree of financial frictions faced by the firm. We first present a partial equilibrium model with labor input only to illustrate the basic intuitions, and then extend the simple model to an economy where firms employ both capital and labor in the production. The partial equilibrium setup allows us to highlight the channels through which financial frictions affects employment, although it can be easily extended to a general equilibrium framework with labor market clearing without changing the main results.

\subsection{A model with labor in production}

Consider a risk neutral firm that hires labor to produce output $Y=A L^{\alpha}$, where $A$ represents productivity and $\alpha \in(0,1)$ measures the degree of returns to scale. Following the standard setup in the working capital literature, we assume that the firm needs to pay a fraction $\theta$ of wages $w L$ in advance (see for example Neumeyer and Perri, 2005[23]). The remaining wages are paid after the firm receives its revenue. To finance working capital, the firm can borrow from a bank with a gross interest rate $R .4^{4}$

With limited commitment and asymmetric information, in the event of default the bank can only recover $\lambda$ fraction of the net operating profits from the firm. As a result, the bank will only lend to the firm up to such a limit:

$$
\theta R w L \leq \lambda\left[A L^{\alpha}-(1-\theta) w L\right]
$$

$\lambda$ essentially measures the degree of financial frictions faced by the firm. Greater $\lambda$ implies that the firm is less financially constraint and able to borrow more with the same amount of pledged profits. From a macro point of view, $\lambda$ also reflects the degree of financial development in an economy, which can in turn be driven by banks' ability to mitigate information asymmetry in lending, the degree of competition between banks, and the quality of institutions in general.

\footnotetext{
${ }^{4}$ For simplicity, here we assume that working capital is fully financed through external borrowing. An alternative setup is to introduce an initial wealth so that the firm only needs to finance part of the working capital externally. This will only complicate the algebra, but all main results remain unchanged.
} 
Taking prices $R$ and $w$ as given, the firm chooses $L$ to maximize the following net profit:

$$
A L^{\alpha}-\theta R w L-(1-\theta) w L
$$

subject to the borrowing constraint in (2). Let $\eta$ denote the multiplier associated with the borrowing constraint. The optimization problem yields the following first-order conditions:

$$
\begin{gathered}
\alpha A L^{\alpha-1}=[\theta R+(1-\theta)] w-\eta\left[\lambda \alpha A L^{\alpha-1}-\lambda(1-\theta) w-\theta R w\right] \\
\lambda\left[A L^{\alpha}-(1-\theta) w L\right]-\theta R w L \geq 0 ; \text { equal if } \eta>0 .
\end{gathered}
$$

Using equation (3), it is straightforward to show that the borrowing constraint (2]) introduces a wedge in the optimal decision of labor demand. Let $M C^{*}=[\theta R+(1-\theta)] w$, which is the marginal cost of labor in the absence of any financial frictions. When $\eta=0$, the marginal product of labor is equal to $M C^{*}$, which yields the first-best level of labor. When $\eta>0$, however, the borrowing constraint is binding. In this case, the marginal product of labor is greater than $M C^{*}$ and the optimal level of labor is below the first best. In addition, it is straightforward to see that the wedge is strictly decreasing in $\lambda$. That is, higher $\lambda$ implies a more relaxed constraint for the firm, which leads to a smaller wedge between the marginal product of labor and $M C^{*}$.

Let $\hat{L}$ be the choice of labor input when the borrowing constraint is binding and $L^{*}$ be the unconstrained first-best choice. Using $(3)$ and $(4)$, the optimal decision of the firm is described in the following proposition.

Proposition 1 Given parameter values of $\alpha, \theta$ and $R$, there exists a cut-off level $\hat{\lambda}=\frac{\alpha R \theta}{R \theta+(1-\alpha)(1-\theta)}$, such that

(i) for $\lambda<\hat{\lambda}$, the financial constraint is always binding and the optimal labor demand is

$$
\hat{L}=\left[\frac{\lambda A}{[R \theta+\lambda(1-\theta)] w}\right]^{\frac{1}{1-\alpha}} ; \text { and }
$$

(ii) for $\lambda \geq \hat{\lambda}$, the financial constraint does not bind and the optimal labor demand is

$$
L^{*}=\left[\frac{\alpha A}{[R \theta+(1-\theta)] w}\right]^{\frac{1}{1-\alpha}} .
$$




\section{Proof: See Appendix A.}

Notice that under standard assumptions, the cut-off value $\hat{\lambda}$ is increasing in both $\alpha$ and $\theta$. That is, all else equal, firms with a greater labor share in production or larger financing need for working capital are more likely to face a binding credit constraint. Once constrained, the allocation $\hat{L}$ is increasing in the labor share and decreasing in working capital financing. Furthermore, $\hat{L}$ is increasing in $\lambda$, so a reduction in financial frictions has a positive effect on labor. The effect of financial constraint on employment works through two channels in this model. While tighter financial constraint restricts the firm's ability to acquire working capital and thus increases the marginal cost of labor, it also reduces the marginal benefit of hiring labor as the firm's pledged profit to borrow increases with labor ${ }^{5}$

We now examine how the marginal effects of financial frictions on employment vary with different parameters. First, it is straightforward to show that $d\left(L^{*}-\hat{L}\right) / d \lambda<0$, so firms that are subject to larger financial frictions would benefit more from a relaxation of the constraints. Next, using $(5)$, one can derive the following (see Appendix A for the proof):

$$
\frac{\partial d \ln \hat{L} / d \lambda}{\partial \lambda}<0, \quad \frac{\partial d \ln \hat{L} / d \lambda}{\partial \alpha}>0, \quad \text { and } \quad \frac{\partial d \ln \hat{L} / d \lambda}{\partial \theta}>0
$$

These results imply that, all else equal, the marginal gain on employment growth from alleviating financial constraint is larger for firms that (i) are more financially constrained, (ii) have a higher labor share, and (iii) rely more on external financing to meet the demand for working capital. The intuition behind these results is straightforward, particularly those with respect to $\alpha$ and $\theta$ : higher labor intensity and greater reliance on external finance for working capital make the firm's employment more responsive to variations in its borrowing constraint. As for the first inequality: although an improvement in financial condition allows a firm to have higher job growth, the marginal return is diminishing in $\lambda$, that is, the resulting gain on employment growth from a higher $\lambda$ is smaller for firms that are less financially constrained to begin with.

The analytical results in expression (7) present several testable predictions that explain the heterogeneous effects of removing financial frictions on employment growth across firms. So

\footnotetext{
${ }^{5}$ The second effect is rather a novel feature of this model, as the borrowing limit depends on the firm's net profit which is in turn positively related to labor inputs. An alternative version would be to simply assume the firm's borrowing is subjected to a fixed upper limit $\bar{b}$. In this case, the effect of an increase in $\lambda$ on the marginal benefit does not exist, but the damping effect on the marginal cost remains.
} 
far we consider an economy with firms using labor input only in their production. One may argue that this simple setup may have restricted other possible links between financial frictions and a firm's optimal decision. In the next section, we extend the baseline model by introducing capital in the production function and show that the main results remain unchanged under certain conditions.

\subsection{A model with both labor and capital in production}

The main structure of economy is similar to the one in the simple model. Now in addition to hiring labor, the firm also needs to rent capital to produce output $Y=A K^{\beta} L^{\alpha}$, where $\alpha$ measures the labor share and $\beta$ the capital share. Let $p_{K}$ be the rental price of capital. Similar to the working capital assumption above, we assume that a fraction $\theta$ of the total input $\operatorname{cost}\left(w L+p_{K} K\right)$ has to be paid before the firm receives revenue, and the remaining $(1-\theta)$ is paid afterwards. Thus, the firm's borrowing constraint becomes:

$$
\theta R\left(w L+p_{K} K\right) \leq \lambda\left[A K^{\beta} L^{\alpha}-(1-\theta)\left(w L+p_{K} K\right)\right]
$$

Taking prices $R, w$ and $p_{K}$ as given, the firm chooses $L$ and $K$ to maximize the net profit:

$$
A K^{\beta} L^{\alpha}-\theta R\left(w L+p_{K} K\right)-(1-\theta)\left(w L+p_{K} K\right)
$$

subject to the borrowing constraint in $(8)$. Let $\hat{K}$ be the choice of capital when the borrowing constraint is binding and $K^{*}$ be the unconstrained choice. Solving the firm's optimization problem yields the results in the following proposition.

Proposition 2 Given parameter values of $\alpha, \beta, \theta$ and $R$, there exists a cut-off level $\hat{\lambda}=\frac{(\alpha+\beta) R \theta}{R \theta+(1-\alpha-\beta)(1-\theta)}$, such that

(i) for $\lambda<\hat{\lambda}$, the financial constraint is always binding and the optimal decision of labor is

$$
\hat{L}=\left[\frac{\alpha \lambda A\left(\frac{\beta w}{\alpha p_{K}}\right)^{\beta}}{(\alpha+\beta)[R \theta+\lambda(1-\theta)] w}\right]^{\frac{1}{1-\alpha-\beta}}, \text { and } \hat{K}=\left[\frac{\alpha \lambda A\left(\frac{\beta w}{\alpha p_{K}}\right)^{1-\alpha}}{(\alpha+\beta)[R \theta+\lambda(1-\theta)] w}\right]^{\frac{1}{1-\alpha-\beta}}
$$


(ii) for $\lambda \geq \hat{\lambda}$, the financial constraint does not bind and the optimal decision of labor is

$$
L^{*}=\left[\frac{\alpha A\left(\frac{\beta w}{\alpha p_{K}}\right)^{\beta}}{[R \theta+\lambda(1-\theta)] w}\right]^{\frac{1}{1-\alpha-\beta}}, \text { and } K^{*}=\left[\frac{\beta A\left(\frac{\alpha p_{K}}{\beta w}\right)^{\alpha}}{[R \theta+\lambda(1-\theta)] p_{K}}\right]^{\frac{1}{1-\alpha-\beta}}
$$

Proof: See Appendix A.

In this model, the financial constraint in $(8)$ introduces a wedge in the optimal decisions of both labor and capital. Similar as in the labor-only model, both wedges are strictly decreasing in $\lambda$. In other words, alleviating financial frictions leads to smaller wedges between the marginal products of inputs and their marginal costs at the first best levels. Moreover, under standard assumptions, the cut-off value $\hat{\lambda}$ is increasing in $\alpha, \beta$, and $\theta$. Different from the results in the laboronly model, the effect of improving financial condition on employment growth depends on the degree of returns to scale. More specifically, we can prove the following (see Appendix A for the proof):

$$
\frac{d \ln \hat{L}}{d \lambda}>0 \text { if } \alpha+\beta<1, \text { and } \frac{d \ln \hat{L}}{d \lambda}<0 \text { if } \alpha+\beta>1
$$

That is, when the firm faces decreasing returns to scale, alleviating financial constraint allows the firm to hire more labor; with increasing returns to scale, however, the correlation between a reduction in financial frictions and employment growth becomes negative ${ }^{6}$ The direct channel through which financial frictions affect employment growth is the same as that in the labor-only model - alleviating financial frictions allows the firm to acquire more working capital and increases the marginal benefit of hiring. The presence of capital input, however, introduces an additional indirect effect. While the positive effect of a reduction in financial frictions on capital leads to a higher profit and allows the firm to borrow more to hire labor, renting more capital also creates a competition in the use of working capital. In equilibrium, the net effect depends on the relative share of labor and capital inputs. When the capital share $\beta$ is relatively large (i.e. $\beta>1-\alpha$ ), the negative effect dominates and relaxing financial constraint in fact makes the firm hire less labor.

The marginal effect of financial frictions on employment growth varies in a similar way with parameters as in the baseline labor-only model, particularly in the case of decreasing returns to

\footnotetext{
${ }^{6}$ we cannot consider the case of constant return to scale, as $\mathrm{K}$ and $\mathrm{L}$ cannot be solved independently in this case.
} 
scale. Using (9), we can derive the following results (see Appendix A for the proof):

(i) $\frac{\partial d \ln \hat{L} / d \lambda}{\partial \alpha}>0$ and $\frac{\partial d \ln \hat{L} / d \lambda}{\partial \beta}>0$, for all values of $\alpha$ and $\beta$, and

(ii) $\quad \frac{\partial d \ln \hat{L} / d \lambda}{\partial \lambda}<0$ and $\frac{\partial d \ln \hat{L} / d \lambda}{\partial \theta}>0$, if $\alpha+\beta<1$.

Same as in the baseline model, these results suggest that, for firms that have decreasing returns to scale, the marginal gains on employment growth from an alleviation of financial frictions are larger when the firm (i) is more financially constraint, (ii) relies more on external financing for working capital, and (iii) has a greater labor or capital input share (or a lower profit share).

\section{Baseline empirical analysis}

The implications of the theoretical models presented in the previous section allow us to formulate the following predictions regarding the differential effects of financial frictions on employment growth across firms.

All else equal,

i) the marginal gains on employment growth from reducing financial frictions are higher for firms with a tighter financial constraint; to the extent that a firm's initial financial constraint can be proxied by its initial size (i.e. smaller firms are more financially constrained), small firms benefit more from a reduction in financial frictions in terms of employment growth than large firms.

ii) for any firm, the higher its labor share and the lower its profit share, the larger is the effect of reducing financial frictions on its employment growth; and

iii) firms that rely more on external resources to finance working capital benefit more from alleviating financial constraint in terms of employment growth.

In the following, we test these predictions empirically using different identification strategies on firm-level survey data covering a large sample of EMDCs.

In the first part of the empirical analysis, we use the comprehensive WBES dataset covering all 134 countries between 2006 and 2015. Although many countries are surveyed over multiple years, not all surveys have been consistently following the same set of firms over time. We therefore first analyze this repeated cross-sectional data along 4 dimensions (firm $i$, industry $j$, country $c$, year $t$ ) 
by estimating the following equation for the firm-level employment growth:

$$
\Delta e_{i j c t}=\alpha_{j c t}+\beta X_{i j c t}+\gamma D_{i j c t}^{f c}+\varepsilon_{i j c t}
$$

where the effect of financial constraint on employment growth in firm $i$ is estimated using dummy variable $D^{f c}$. This dummy variable is encoded using the firm's response to the survey question "How much of an obstacle is access to finance?", with the answer being on an ordinal scale between 0 (no obstacle) to 4 (severe obstacle). We code the the dummy variable equal to 1 for all firms that indicate that access to finance is a major obstacle (3) or severe obstacle (4). We include an industry-country-year fixed effect in our estimation. Hence, the regression exploits the variation of employment growth and the degree of financial constraint faced by firms within an industrycountry-year cell, with the industry being at the 4-digit level of disaggregation. Following the literature, we also control for other firm-level variables, $X_{i j c t}$ that are known to be linked with firm growth, including firm age, initial size, exporter status, share of foreign or public ownership, and importantly, initial (labor) productivity.

The employment growth rate that the survey allows to compute is the annualized growth rate between the previous fiscal year and three fiscal years prior, where we use the average of the endpoints for base value calculation as is common in the literature, following Haltiwanger et al. (2013)[18] (i.e. $\Delta e_{t}=\frac{1}{3} \frac{e_{t}-e_{t-3}}{\left(0.5 *\left(e_{t}+e_{t-3}\right)\right)}$. The results are presented in column 1 of Table 1. Within a given industry-country-year cell, a firm that faces a major or severe obstacle in finance has about 1.5 percentage points lower job creation rate (relative to a mean of 5 percent across all firms in the sample) than those face mild or no constraint.

Next, we add the interaction of the financial constraint dummy with the firm-level share of externally financed working capital $w k f_{i}$ taken directly from the survey. This specification allows us to examine how the finance-employment relationship varies with the share of working capital financed externally.

$$
\Delta e_{i j c t}=\alpha_{j c t}+\beta X_{i j c t}+\gamma_{1} D_{i j c t}^{f c}+\gamma_{1} D_{i j c t}^{f c} \times w k f_{i j c t}+\varepsilon_{i j c t}
$$

The results are presented in column 2 to 5 of Table 1 . Column 2 shows that the impact of financial 
constraint on employment growth does depend on the degree of working capital financing as implied by the model. All else equal, a firm that finances 50 percent of its working capital externally experiences 0.5 percentage point lower employment growth than a firm that does not finance its working capital externally (corresponding to the difference between the 75th and 25th percentile of the overall $w k f_{i}$ distribution), when subject to the same financial constraint (column 2), with the differential being statistically significant at the 10 percent level (standard errors clustered at the $j$ ct cell level).

The question arises regarding the endogeneity of the $w k f$ share at the firm level. Factors determining employment growth at the firm level (say through profitability) could also determine how much a firm chooses to finance its working capital externally $]^{7}$ We address this potential endogeneity in two different ways. First, we restrict our analysis to manufacturing industries only. As we have shown in Figure 2 , a substantial share of working capital financing in those industries is pinned down by intrinsic characteristics of the production process, so the endogeneity issue is somewhat mitigated. As shown in column 3, our previous results remain broadly unchanged. Next, we compute the average $w k f_{i}$ over all firms in a given $j c t$ cell to obtain a measure of liquidity financing needs that is less influenced by firm-specific omitted variables. We re-estimate 14 using this new measure of $w k f$. Column 4 reports the results. All coefficients of our main interest remain statistically significant. As anticipated, using the country-industry-year specific $w k f$ share, the marginal effect of changes in working capital financing on the finance-employment relationship is twice as large as the previous estimates, but the unconditional effect is smaller than before.

Another concern related to the endogeneity of the $w k f$ share is that firms in countries and industries that are less profitable or grow slower rely more on external credit to finance their working capital, as they may have lower cash flows. We address such endogeneity by forming the $j c t$-level average $w k f$ share only using firms that indicate that they are not financially constrained $(D f c=0)$, to approximate an unconstrained or technology driven measure of liquidity financing needs. Column 5 shows that the results are similar to that using the overall averaged share. In terms of magnitude, a financially-constrained firm in an industry-country-year cell with an aver-

\footnotetext{
${ }^{7}$ Note that such factors would be positively correlated with employment growth and $w k f$, and hence bias the interaction term toward zero.
} 
age share of working capital financing needs of 40 percent (75th percentile) creates 1.75 percentage point less jobs than a similar but unconstrained firm, while the difference is only 1.2 percentage points for firms in industry-country-year cells with 15 percent liquidity financing needs (25th percentile).

Finally, we test how the finance-employment relationship varies with firm size and labor intensity. In our theoretical model, working capital consists of labor costs and part of the capital spending, whereas in the data, working capital comprises also outlays for intermediate inputs, material and other operating expenses, such as rent, energy costs etc. To reflect these differences, we calculate the share of labor cost in total operational expenses by dividing labor cost (including salaries, bonuses, benefits etc.) by the sum of all the three cost categories. This firm-level measure of labor-intensity together with the measure of labor intensity in production, allow us to test some key predictions of the model. That is, for given liquidity financing needs, the magnitude of the effect of relaxing financial constraint on employment growth is increasing with labor intensity and decreasing with firm size (as a firm's size is often negatively correlated with its labor intensity in the production). Table 2 summarizes the regression results. We split the sample into firms with high and low share of labor costs in revenues (column 1 and 2), firms with high and low labor costs in working capital (column 3 and 4), and firms with below and above 50 employees (column 5 and 6). As predicted by the model, the interaction term between the financial constraint dummy and working capital financing share that we previously estimated to be overall negative is indeed driven, all else equal, by firms with high labor share in production, high labor cost share in working capital, and in small firms.

\section{Addressing endogeneity}

The main caveat of our identification using repeated cross section is that we cannot rule out the case in which firms who claim to be financially constrained are in fact inherently less productive than those that are unconstrained. Even though we control for initial productivity (in the form of lagged sales per worker), firms can still exhibit diverging productivity going forward when the business environment evolves. If this were the case, the effect we are estimating would in part reflect the fact that less productive or less profitable firms create fewer jobs, and not necessarily 
the effect of financial constraint on employment growth.

We address this endogeneity problem with three strategies. First, we examine whether firms that claim to be financially constrained also have poor performance ex post in terms of profitability, controlling for all other observable determinants of firm performance in the baseline regressions (age, ownership, export status, etc). If there is systematic selection of firms with low growth potentials reporting financial obstacles in the survey group, we would expect to observe lower productivity growth in these firms versus comparable firms that report unconstrained. Second, we use a subset of the WBES which has been following individual firms over time in Central and Eastern Europe, the so-called BEEPS (Business Environment and Enterprise Performance Survey) database, to control for unobservable firm fixed effects. In contrast to the regressions in the previous section which examine variation in employment growth across firms, we exploit variation within firms in response to changes in the perception of financial obstacles. This panel setup allows us to control for firm-level unobservables and thus overcome a major bias associated with omitted variables. Third, we employ a difference-in-difference strategy to estimate the differential effect of financial development in sectors with varying working capital financing needs. We rely on industry-intrinsic working capital financing needs (averaged across countries) coupled with structural measures of credit contractability across countries. This approach allows us to further account for firm-specific and possibly time-varying omitted variables by relying on differential responses to a common treatment (here changes in contracting environment) across industries with varying needs for working capital financing.

\subsection{Productivity differential}

Regression results summarized in Table 3 replace the dependent variable in the baseline equation 14-employment growth-with log sales per worker. Effectively, what we are estimating is whether, within a given industry-country-year cell, firms that are financially constrained (per survey measure) also have lower sales per worker, as a proxy of profitability. In addition, we add the interaction term to test whether firms with more working capital financing needs have lower profit. In column 1, the interaction term is constructed with the firm-level $w k f$ share, while in column 2 to 5, the industry-country-level, unconstrained firms' average $w k f$ is used. Throughout 
all specifications, there is no evidence that firms which claim to be financially constrained are less productive, at least in terms of relative sales per worker. This implies that unobserved characteristics are unlikely to drive financial constraint and firm performance moving in the same direction. Since we already control for initial sales per worker (in $t-3$ ), the results in Table 3 also suggest that not only the level, but also the growth of productivity between $t-3$ and $t$ is not correlated with the degree of financial constraint, further alleviating the concern of endogeneity.

\subsection{Estimation with firm panel}

In the following, we exploit the panel structure of a subset of surveys conducted by the WBES to control for firm-level unobservables. Through 2002 to 2013, a representative sample of private sector firms in Eastern and Central European countries was surveyed over multiple waves, allowing the creation of a firm panel dataset called BEEPS. The list of countries and years covered by the BEEPS surveys is presented in Appendix Table B.2. Most relevant for our analysis, the same firm is asked over several years about the perception of its access to finance, allowing us to exploit the within-firm variation in financial constraint as opposed to the cross-section variation in the baseline specification. In the following, we estimate the effect of varying financial constraint within-firm across different years of surveys. That is, we estimate:

$$
\Delta e_{i j c t}=\alpha_{c t}+\alpha_{j t}+\alpha_{i}+\beta X_{i j c t}+\gamma_{1} D_{i j c t}^{f c}+\gamma_{2} D_{i j c t}^{f c} \times w k f_{i}+\varepsilon_{i j c t},
$$

The results are presented in Table 4 . The average effect of the reported financial constraint on firm-level employment growth is very similar between the within-firm result and the previous cross-section one: controlling for observable initial conditions, financial constraint reduces employment growth in a given firm by 1.2 percentage points (compared to $1.5 \mathrm{ppt}$ in the repeated cross-section regression). The difference-in-difference estimate of the effect of financial constraint is stronger in the panel regression than that in the cross-section regression (column 2 in Table 4 vs. column 5 in Table 1). A firm at the 75th percentile of the working capital financing need distribution (40 percent of working capital financed externally) experiences 2.2 percentage point lower job

creation when it is financially constrained relative to unconstrained times. The same differential is only 0.8 percent for a firm in the 25th percentile of working capital financing needs distribution 
(15 percent of working capital financed externally).

By controlling for firm-level unobservable fixed effects, we can rule out the case that the effect we are estimating is driven by inherently lower productivity firms claiming to face obstacle in financing. However, variation of financial access within a firm could also be endogenous to firm-specific but time-varying idiosyncratic productivity shocks, even though we do control for country-year and 4-digit industry-year specific fixed effects to absorb macro and industry-level demand effects. In column 3 of Table 4 , we use the system-GMM estimator of Blundell and Bond (1998)[10] to estimate the same firm-panel regression, but allowing all firm-level right-hand-side variables, including the financial constraint dummy and the degree of working capital financing needs, to be potentially endogenous. Following standard practice in the literature, firm-level controls are instrumented in first differences by their own lagged levels. The results yield, as expected, less precise estimates, but deliver the same estimate of the employment effect of financial constraint through the working capital channel. Another way to check for endogeneity of financial constraint is to estimate whether firms are less productive (in terms of sales per worker) when they claim they are more financially constrained (column 4). As in the cross-sectional analysis, we do not find any evidence of such a correlation between reported financial constraint and sales/worker, alleviating the concern of performance related endogeneity. Finally, in column 5 and 6, we again show that the effect of financial access on employment through the working capital channel operates mainly for small firms, as implied by the model, whereas the effect is not statistically significant for large firms.

\subsection{Distinction from fixed capital channel}

While our theoretical framework and empirical analysis highlight the working capital financing channel for financial development to foster employment growth, we have so far not examined whether the effect is in fact driven by the positive effect of financial development on fixed capital investment and associated employment growth if labor and capital are complements. As discussed above, previous studies often highlight the importance of external financing of fixed capital for overall growth in income and productivity. However, it is not obvious that the fixed capital channel would be the most important one for boosting employment growth, as capital 
deepening can also be associated with lower employment growth (see Karabarbounis and Neiman (2013)[20]). In the following, we disentangle the two channels by estimating:

$$
\Delta e_{i j c t}=\alpha_{j c t}+\beta X_{i j c t}+\gamma_{1} D_{i j c t}^{f c}+\gamma_{2} D_{i j c t}^{f c} \times w k f_{j}+\gamma_{3} D_{i j c t}^{f c} \times e f d_{j}+\varepsilon_{i j c t},
$$

where $w k f_{j}$ stands for the average industry-specific share of working capital that is financed externally (averaged over all firms with non-missing data in the WBES sample who do not report financial obstacle), while $e f d_{j}$ denotes the industry-specific external financial dependence as defined by Rajan and Zingales (1998)[26] using data from publicly listed firms in the U.S. from Compustat $:^{8}$ Both measures aim to capture the degree of external financial dependence for working capital and fixed capital that is intrinsically driven by technology and/or product market characteristics, as opposed to by country or period-specific variation in financing conditions. If the effect of finance on employment mainly goes through the channel of fixed capital complementarity, we would expect $\gamma_{3}$ to be negative and the previously estimated coefficient $\gamma_{2}$ to be zero. Table 5 summarizes the estimation result of equation (16) using the repeated cross-section as well as firm panel.

As in the baseline result, financial constraints reduce employment growth for small firms that are more reliant on working capital financing (estimate of $\gamma_{2}$ has similar magnitude and statistical significance as before). Interestingly, financial obstacles do not appear to inhibit employment growth disproportionately more for firms that are intrinsically more dependent on external financing for fixed capital investment (estimate of $\gamma_{3}$ not significantly different from zero), regardless of firm size (column 1-3). Results are similar when estimated using within-firm variation (column 4-6). These results suggest that less access to finance reduces employment growth within small firms, particularly within small firms that are more reliant on working capital financing, while the same does not hold for those more reliant on external financing for fixed capital. The absence of a statistically significant effect through the fixed capital financing channel on employment is consistent with the view that increased investment in fixed capital allows a subset of firms to substitute capital for labor (that is, the elasticity of substitution in their production function is high), offsetting the positive effect of higher fixed capital on employment in other firms (whose production has a lower elasticity of substitution between factors). The effect of financial constraint on employ-

\footnotetext{
${ }^{8}$ More specifically, the index is computed as efd $=\frac{\text { Capex-CashFlow }}{\text { Capex }}$ for each firm and taken as median across all firms in Compustat USA Industrial Annual in each 3-digit SIC industry over the period 1990-2006.
} 
ment grwoth in small firms through the working capital channel, in contrast, is unambiguously negative.

\subsection{Difference-in-difference estimation}

In the final empirical exercise, we provide further evidence of a working capital channel of finance on employment by estimating the following difference-in-difference regression equation:

$$
\Delta e_{i j c t}=\alpha_{c t}+\alpha_{j t}+\beta C r e d i t I n d e x_{c t} \times w k f_{j}+\varepsilon_{i j c t},
$$

where $w k f_{j}$ is the working capital financing need measure aggregated over all firms in all countries for each given industry, and CreditIndex $x_{c t}$ is the indicator measuring the strength of credit reporting systems and the effectiveness of collateral and bankruptcy laws in facilitating lending in each country, constructed and updated annually by the World Bank's DoingBusiness report. Effectively, we are collapsing employment growth into $j c t$-level cells and estimating the effect of varying financial constraint triggered by changing structural measures of credit contractibility at the country level, interacted with variations in the working capital financing needs of the specific industry. If the channel we uncovered above is operative, an improvement in the contracting environment that makes institutions more conducive to channeling credit to appropriate businesses should benefit job creation more for firms in industries that rely more on external finance to fund their working capital than those industries that rely on less (see discussion around Figure 2 for the factors that drive different reliance on the externally-funded working capital). We therefore expect the coefficient $\beta$ to be positive. Compared to previous specification, this difference-in-difference estimation overcomes remaining endogeneity concerns driven by omitted variables at the firm level, and is thus more amenable to causal interpretation, yet comes with the drawback of only being able to identify a differential impact of financial development.

Results of this difference-in-difference estimation are presented in Table 6. While the estimate is statistically insignificant for large firms, it is positive and statistically significant at 5 percent for small firms. Small firms here are defined as firms with 50 employees or less to be consistent with previous regressions, but the results are robust to changing the cutoff to 20, 25 or 30 employees. In terms of magnitudes, an improvement in credit contractibility from 25th to 75th percentile of the 
indicator distribution, which corresponds to an improvement in contracting environment from the level in Morocco to that in Hungary, can raise employment growth by 6 percentage point per year more for small firms in an industry with 40 percent working capital financing needs compared to an industry with 15 percent working capital financing needs.

\section{Conclusion}

In this paper, we derive and test an under-explored channel through which finance affects job creation at the firm level. While past literature has often established that access to finance matters for employment both at the micro and macro level, no particular channel has been explicitly analyzed. Instead, it was often assumed that the link occurs through complementarity between labor and capital, and relying on the long-established evidence that access to finance affects firms' ability to invest in fixed capital. We argue that even for given fixed capital, firms need external finance to fund their working capital, of which wage payments are an important component. The ease of obtaining external liquidity thus determines the level of employment the firm can support, for given levels of profitability.

We present the working capital channel using a simple model to show how financial constraint in the form of borrowing limit affects a firm's employment growth, and that this relationship is stronger for firms that have a smaller size and more labor-intensive production structure. We then take the key predictions of the model to the data and test them empirically using the World Bank Enterprise Surveys, which provide a comprehensive coverage of private sector firms in EMDCs. We find strong evidence for the working capital channel of finance on firm-level employment growth, with the channel being particularly strong for small, labor-intensive firms. We conduct several robustness exercises to alleviate concerns of omitted variables and endogeneity of (reported) financial constraint by controlling for external financial dependence of fixed capital investment, analyzing the ex-post difference in firm productivity, controlling for firm fixed effects, and exploiting a difference-in-difference strategy that relies on industry-intrinsic need for working capital financing.

Although our analysis presents evidence of positive effects of relaxing financial constraint on job creation at the firm level, to draw a conclusion on the relationship between financial devel- 
opment and aggregate employment growth, one would need to account for general equilibrium effects such as the response of non-constrained firms, aggregate wage levels and labor supply. That said, a look at prima-facie evidence shows that a reduction in the share of firms facing financial constraint at the country level tends to be associated with overall stronger employment growth, even conditional on the underlying growth in income (Figure 5) 9 This suggests that the offsetting effects from any general equilibrium changes may be small. Concerns about unemployment and low productivity has been gaining acuteness since the global financial crisis. Though the policy discussion in this context has been focusing on the need for structural reforms, our paper serves as a reminder that finance and the availability of external liquidity remain crucial to allow firms to translate any gains in efficiency into actual jobs. This, in turn, allows income gains to be more evenly distributed among workers and capital owners, alleviating adverse effects of financial deepening on inequality.

\footnotetext{
${ }^{9}$ Figure 5 shows the correlation between (full-time, formal) employment growth at the country level and the share of employment in small financially-constrained firms (both variables are aggregates over all firms weighted by their sampling weight in the WBES) for all countries with more than one wave of survey. The correlation nets out the average effect of GDP growth and controls for country and year fixed effects.
} 


\section{References}

Arcand, J.-L., E. Berkes, And U. PAnizZA (2012): “Too Much Finance?,” IMF Working Paper 12/161, International Monetary Fund Washington DC.

Ayyagari, M., A. Demirguc-Kunt, And V. MaKsimovic (2014): “Who creates jobs in developing countries?," Small Business Economics, 43(1), 75-99.

Ayyagari, Meghana; Juarros, P. F. M. P. M. S. S. S. (2016): “Access to finance and job growth: firm-level evidence across developing countries," Policy Research Working Paper WPS6704, World Bank.

Bacchetta, P., K. Benhima, And C. Poilly (2014): “Corporate Cash and Employment,” CEPR Discussion Papers 10309, C.E.P.R. Discussion Papers.

BECK, T. (2013): “Bank Financing for SMEs — Lessons from the Literature," National Institute Economic Review, 225(1), 23-38.

BECK, T., A. DEMIRGUC-KUNT, L. LAEVEN, AND R. LEVINE (2008): “Finance, Firm Size, and Growth," Journal of Money, Credit and Banking, 40(7), 1379-1405.

Beck, T., A. Demirguc-Kunt, And V. MaKsimovic (2005): “Financial and Legal Constraints to Growth: Does Firm Size Matter?," The Journal of Finance, 60(1), 137-177.

BECK, T., AND R. LEVINE (2004): “Stock Markets, Banks and Growth: Panel Evidence," Journal of Banking and Finance, 28(3), 42342.

Benmelech, E., N. K. Bergman, And A. Seru (2011): “Financing Labor,” Working Paper 17144, National Bureau of Economic Research.

BLUNDELL, R., AND S. BOND (1998): “Initial conditions and moment restrictions in dynamic panel data models," Journal of Econometrics, 87(1), 115 - 143.

CARlson, J. A. (1973): “The Production Lag,” American Economic Review, 63(1), 73-86.

Catao, L., C. Pages, And M. F. Rosales (2009): “Financial Dependence, Formal Credit and Informal Jobs: New Evidence from Brazilian Household Data," IDB Publications (Working Papers) 4123, Inter-American Development Bank. 
Cecchetti, S. G., And E. Kharroubi. (2015): “Why Does Financial Sector Growth Crowd Out Real Economic Growth?," BIS Working Paper 490, Bank for International Settlements, Basel.

CHAN, R. C. (2014): "Financial constraints, working capital and the dynamic behavior of the firm," Policy Research Working Paper WPS6797, World Bank.

Chodorow-Reich, G. (2014): “The Employment Effects of Credit Market Disruptions: Firmlevel Evidence from the 2008-9 Financial Crisis," The Quarterly Journal of Economics, 129(1), 1-59.

GArmaise, M. J. (2008): "Production in Entrepreneurial Firms: The Effects of Financial Constraints on Labor and Capital," Review of Financial Studies, 21(2), 543-577.

Haltenhof, S., S. Jung LeE, And V. StebunOVs (2014): “The credit crunch and fall in employment during the Great Recession," Journal of Economic Dynamics and Control, 43(C), 31-57.

HaltiWAnger, J., R. S. JARmin, And J. Miranda (2013): “Who Creates Jobs? Small versus Large versus Young," The Review of Economics and Statistics, 95(2), 347-361.

Kalemli-Ozcan, S., H. S. Shin, S.-J. Kim, B. E. Sorensen, and S. Yesiltas (2014): “Financial shocks in production chains," Unpublished manuscript.

Karabarbounis, L., And B. NeIMAN (2013): “The Global Decline in the Labor Share,” The Quarterly Journal of Economics, 129(1), 61-103.

Levine, R. (2005): "Finance and Growth: Theory and Evidence," in Handbook of Economic Growth, ed. by P. Aghion, and S. Durlauf, vol. 1 of Handbook of Economic Growth, chap. 12, pp. 865-934. Elsevier.

MiAn, A., AND A. SUfi (2014): “What Explains the 20072009 Drop in Employment?," Econometrica, 82(6), 2197-2223.

Neumeyer, P. A., ANd F. Perri (2005): “Business cycles in emerging economies: the role of interest rates," Journal of Monetary Economics, 52(2), 345-380.

OI, W. Y. (1983): “Heterogeneous Firms and the Organization of Production," Economic Inquiry, 21(2), 147-171. 
PagAnO, M., And G. PiCA (2012): “Finance and employment," Economic Policy, 27(69), 5-55.

RAJAN, R. G., AND L. Zingales (1998): “Financial Dependence and Growth," American Economic Review, 88(3), 559-586.

Sahay, R., M. Cihak, P. N’Diaye, A. Barajas, D. A. Pena, R. Bi, Y. Gao, A. Kyobe, L. Nguyen, C. SAborowski, K. SvirydzenKA, , AND R. Yousefi (2015): “Rethinking Financial Deepening: Stability and Growth in Emerging Markets," IMF Staff Discussion Note SDN/15/08, International Monetary Fund, Washington DC. 
Figure 1: Share of working capital financed externally by industry.

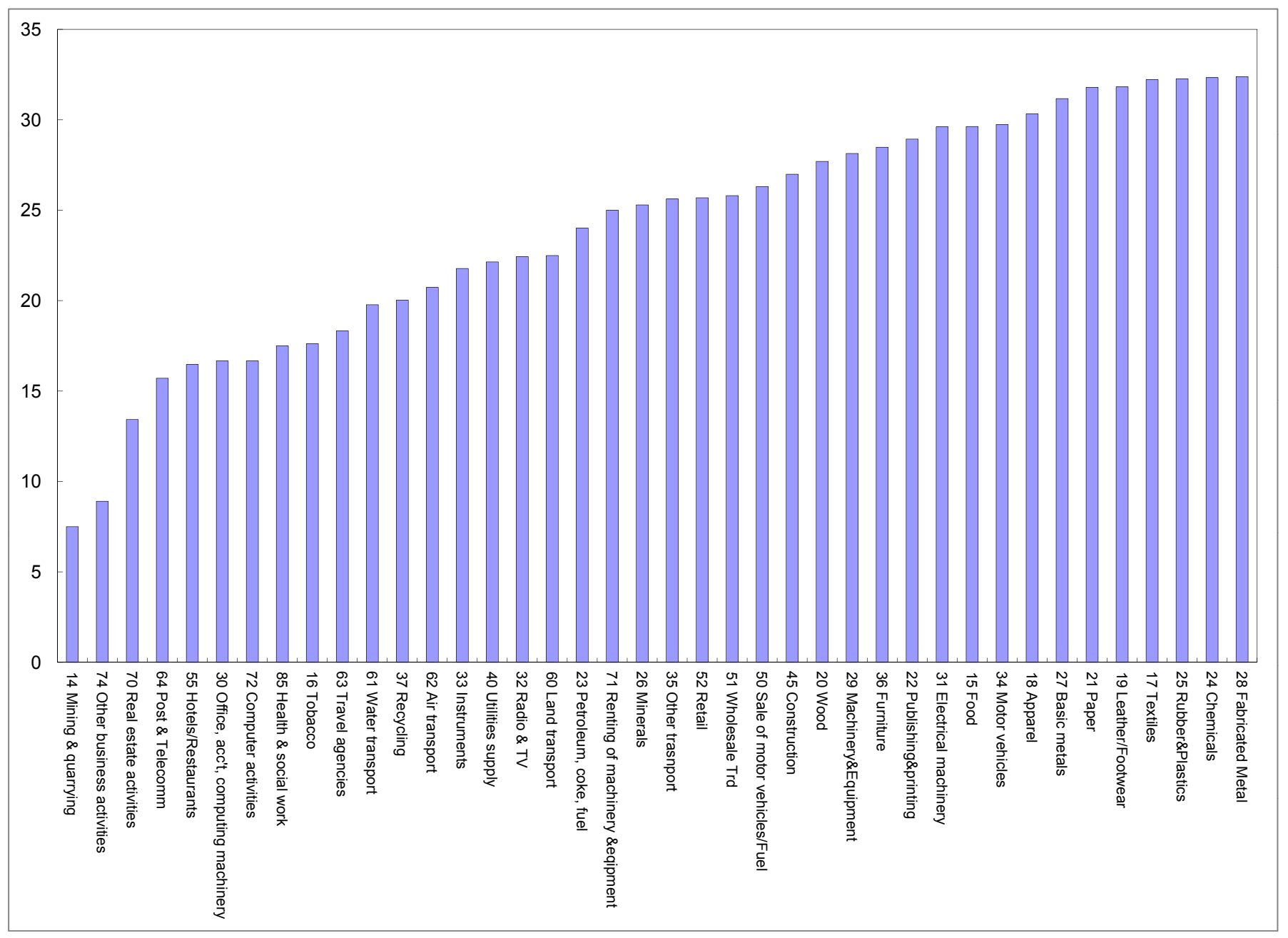

Notes: The share is 1 minus the average share by industry across al firms answering the question "Proportion of working capital financed by internal funds". 
Figure 2: Share of working capital financed externally: actual vs. predicted.

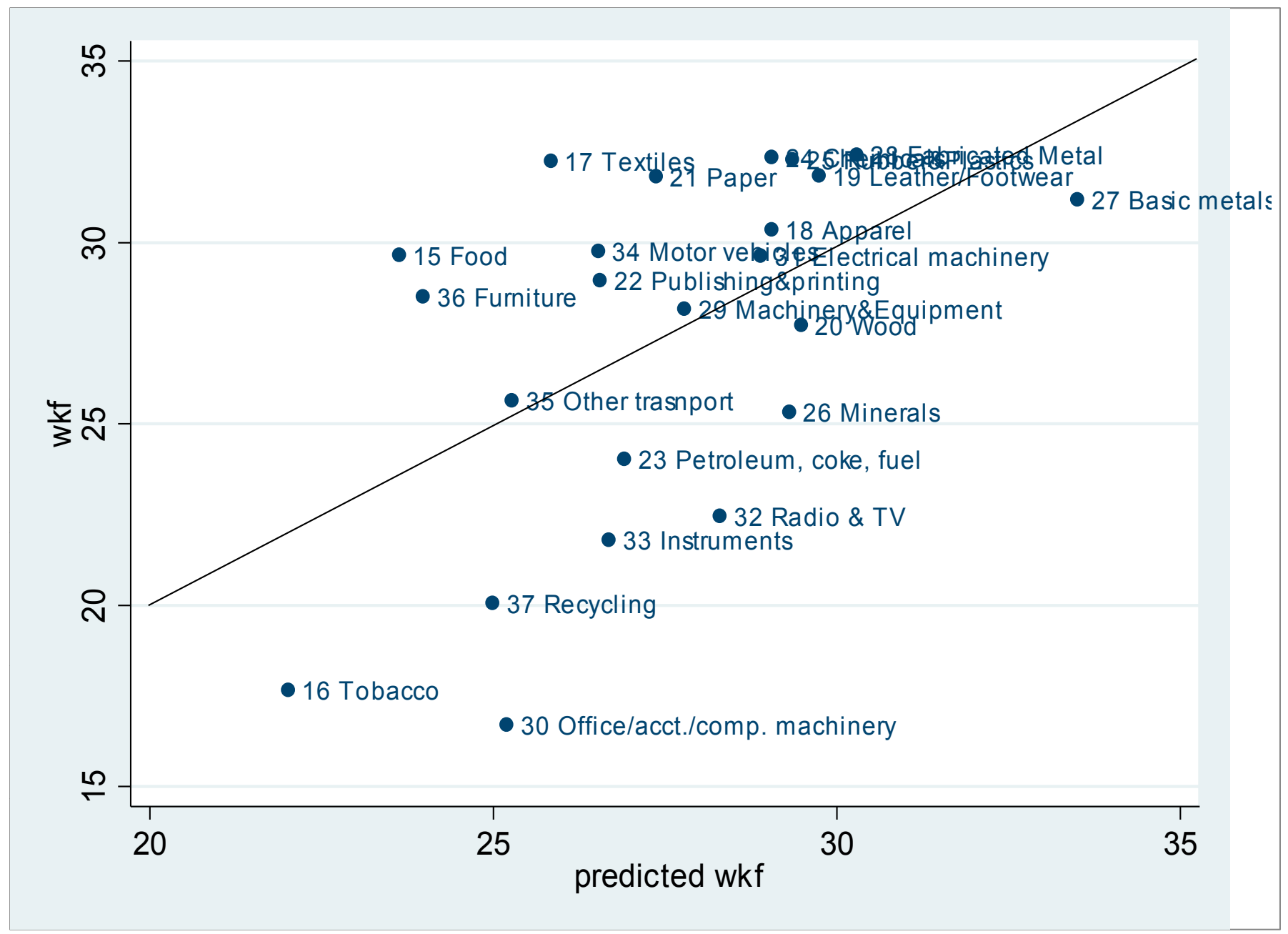

Notes: the predicted share of externally financed working capital (wkf) is computed from regression model 1 in the text. 
Figure 3: Distribution of labor cost share in working capital by firm size
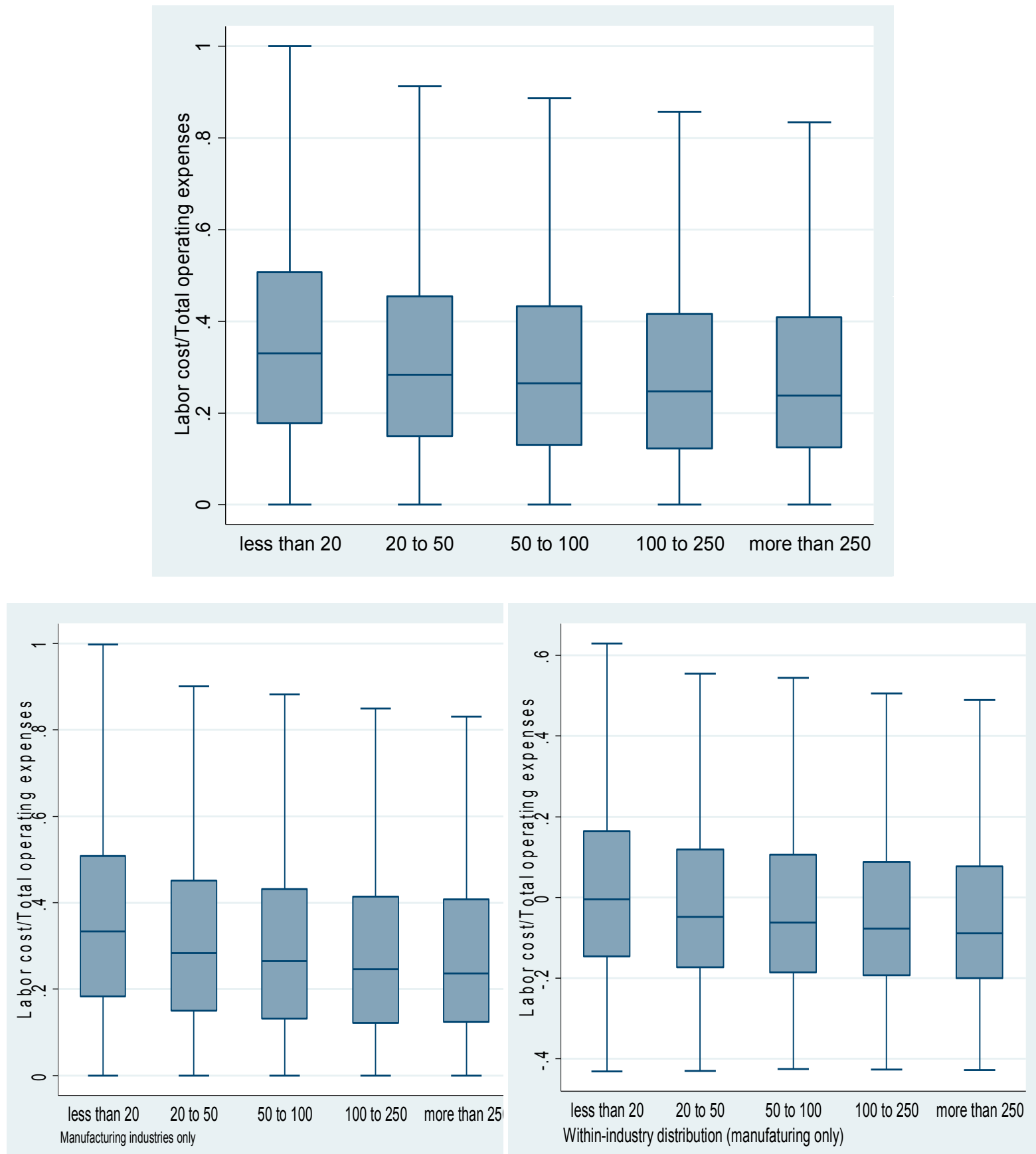

Notes: Box plots are given for each firm size by number of workers. The variable is defined as "Total labor costs" as a share of the sum of "Total labor cost", "Total annual cost of electricity" and "Cost of raw material and intermediate input used in production" as a measure for total operating expenses financed with working capital. First panel includes all industries, second panel only manufacturing industries (ISIC 15 to 37) and last panel shows deviations from (manufacturing) industry-specific means. 
Figure 4: Contribution to employment and job creation by firm size
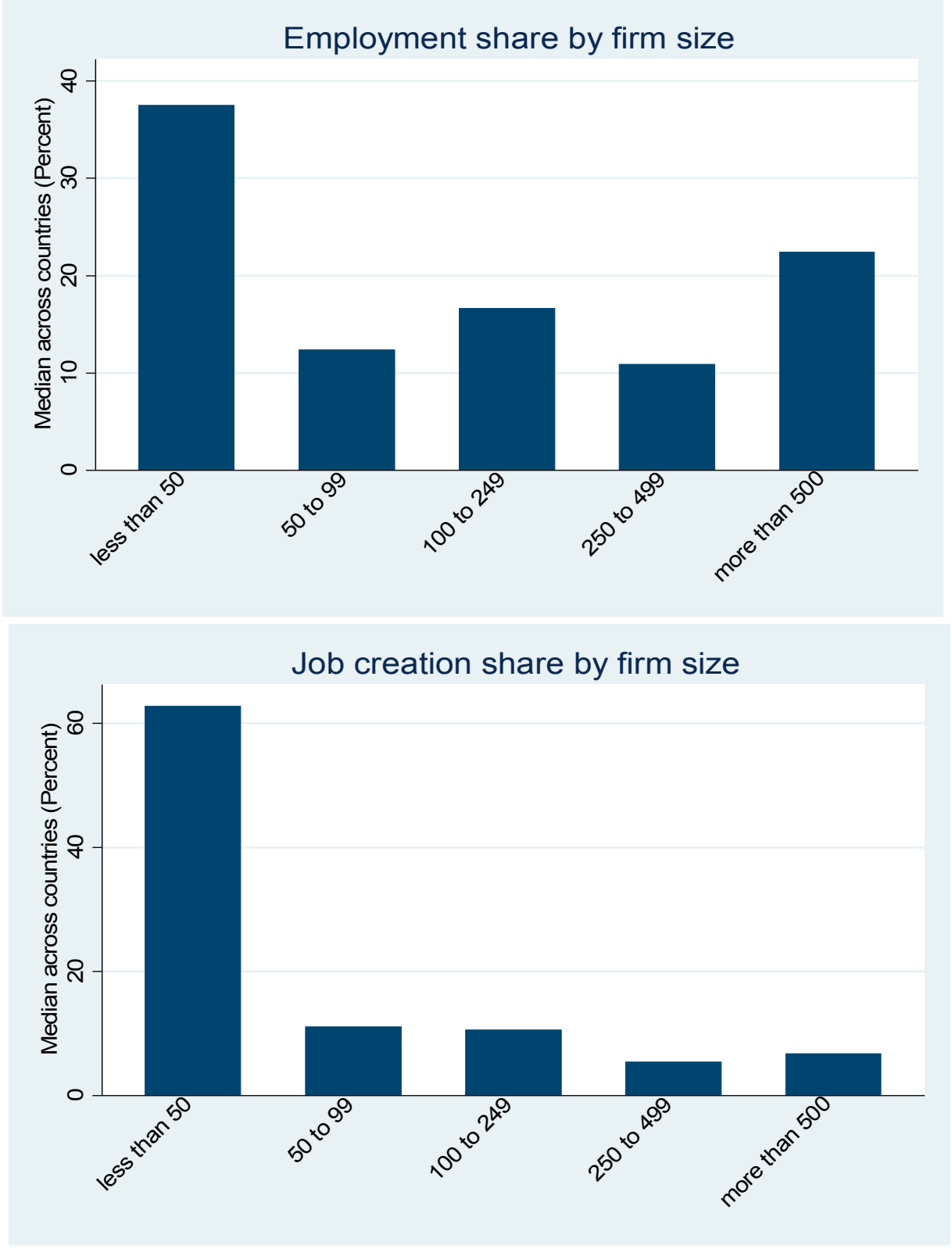

Notes: The sample consists of all survey countries between 2006-2014, within-country variables weighted by stratified sampling weights. Only country-years with positive net job creation are included. 
Figure 5: Correlation between aggregate employment growth and degree of financial constraint for small firms.

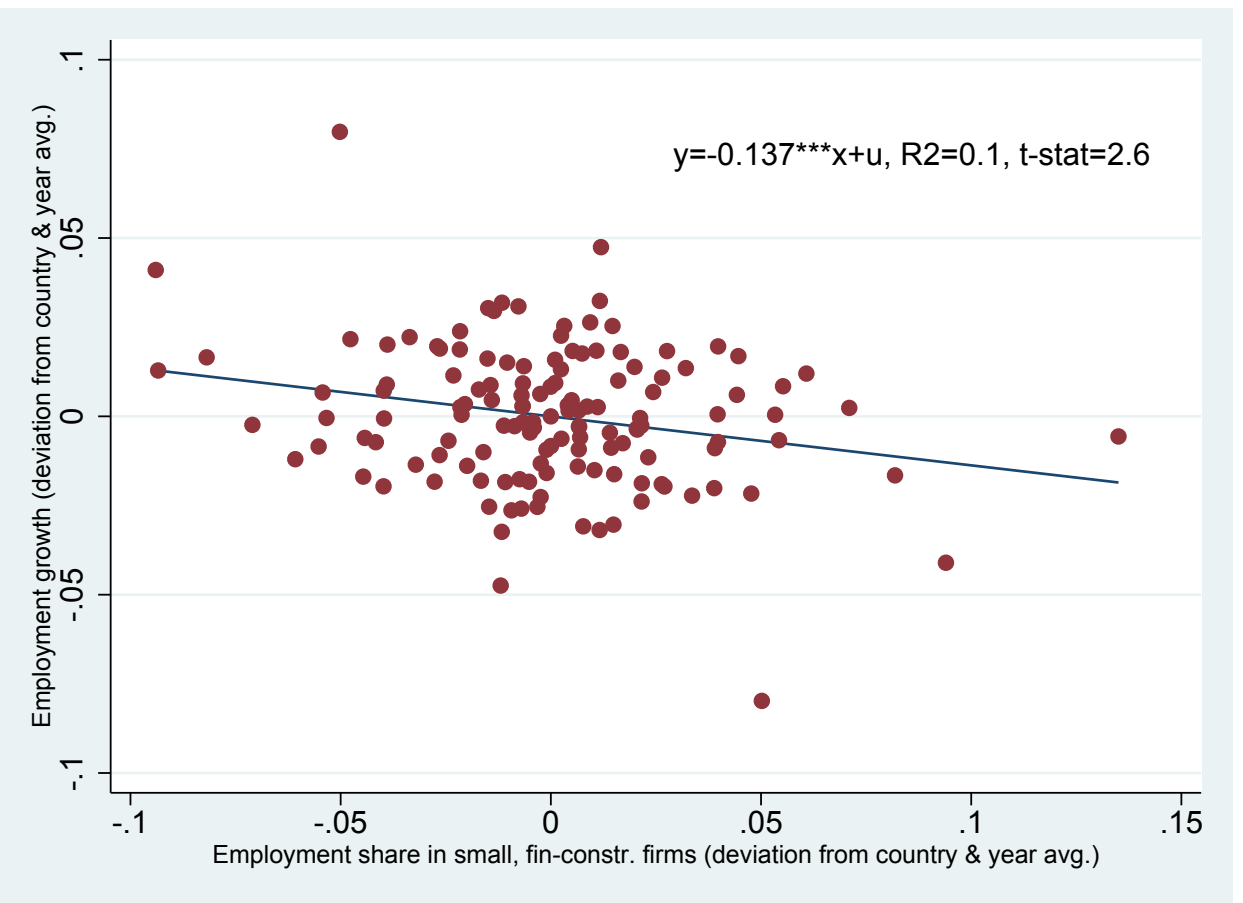

Notes: Each dot represents the aggregated observation for one country-year where employment growth and share of employment in small financially-constrained firms are aggregated from all firms in the survey using their sampling weight. Only countries with multiple surveys are included. Both variables are residuals from a regression on country and year fixed effects, as well as GDP growth over the same period. 
Table 1: Access to finance and firm-level employment: within industry-country-year variation.

\begin{tabular}{|c|c|c|c|c|c|}
\hline & \multicolumn{5}{|c|}{ Dependent variable: Annual employment growth (\%) } \\
\hline & \multirow[t]{2}{*}{$(1)$} & \multirow[t]{2}{*}{$(2)$} & \multirow{2}{*}{$\begin{array}{c}\text { (3) } \\
\text { only manufacturing }\end{array}$} & \multirow{2}{*}{$\begin{array}{c}\text { (4) } \\
\text { industry } w k f_{j}\end{array}$} & \multirow{2}{*}{$\begin{array}{c}(5) \\
\text { unconstr. industry } w \tilde{k} f_{j}\end{array}$} \\
\hline & & & & & \\
\hline$D f c$ & $-1.530 * * *$ & $-1.307^{* * *}$ & $-1.584^{* * *}$ & $-0.898^{* *}$ & $-0.860 * *$ \\
\hline & $(0.151)$ & $(0.252)$ & $(0.268)$ & $(0.395)$ & $(0.344)$ \\
\hline$D f c \times w k f_{i}$ & & $-0.866^{*}$ & $-0.850 *$ & & \\
\hline & & $(0.484)$ & $(0.512)$ & & \\
\hline$D f c \times w k f_{j}$ & & & & $-1.947^{*}$ & \\
\hline & & & & $(1.115)$ & \\
\hline$D f c \times w \tilde{k} f_{j}$ & & & & & $-2.220^{* *}$ \\
\hline & & & & & $(1.004)$ \\
\hline age & $-0.050^{* * *}$ & $-0.064^{* * *}$ & $-0.064^{* * *}$ & $-0.065^{* * *}$ & $-0.065^{* * *}$ \\
\hline & $(0.010)$ & $(0.005)$ & $(0.005)$ & $(0.005)$ & $(0.005)$ \\
\hline$w k f_{i}$ & & $0.015^{* * *}$ & $0.016^{* * *}$ & & \\
\hline & & $(0.002)$ & $(0.003)$ & & \\
\hline log size & $-3.525^{* * *}$ & $-3.378^{* * *}$ & $-3.381^{* * *}$ & $-3.365^{* * *}$ & $-3.354^{* * *}$ \\
\hline & $(0.100)$ & $(0.105)$ & $(0.071)$ & $(0.105)$ & $(0.105)$ \\
\hline $\log$ (Productivity) & & $1.172^{* * *}$ & $1.444^{* * *}$ & $1.164^{* * *}$ & $1.157^{* * *}$ \\
\hline & & $(0.084)$ & $(0.052)$ & $(0.082)$ & $(0.083)$ \\
\hline Foreign ownership & $2.076^{* * *}$ & $1.429^{* * *}$ & $1.330^{* * *}$ & $1.319^{* * *}$ & $1.347^{* * *}$ \\
\hline & $(0.247)$ & $(0.278)$ & $(0.309)$ & $(0.275)$ & $(0.276)$ \\
\hline Exporter & $3.767^{* * *}$ & $3.228^{* * *}$ & $3.580^{* * *}$ & $3.286^{* * *}$ & $3.282^{* * *}$ \\
\hline & $(0.192)$ & $(0.220)$ & $(0.229)$ & $(0.218)$ & $(0.218)$ \\
\hline Govt. ownership & 0.566 & $1.982^{* * *}$ & $2.690^{* * *}$ & $2.161^{* * *}$ & $2.103^{* * *}$ \\
\hline & $(0.559)$ & $(0.666)$ & $(0.752)$ & $(0.649)$ & $(0.653)$ \\
\hline Constant & $16.074^{* * *}$ & -0.127 & $-3.528^{* * *}$ & 0.382 & 0.440 \\
\hline & $(0.284)$ & $(1.171)$ & $(0.736)$ & (1.155) & (1.157) \\
\hline Observations & 90,509 & 63,647 & 43,743 & 64,423 & 62,811 \\
\hline R-squared & 0.068 & 0.078 & 0.089 & 0.078 & 0.078 \\
\hline Number of $j c t$ cells & 15,105 & 11,305 & 7,586 & 11,328 & 10,076 \\
\hline
\end{tabular}

Note: All regressions effectively control for $j c t$-cell level fixed effects. Robust standard errors in parentheses are clustered at the $j c t$ level, ${ }^{* * *} \mathrm{p}<0.01,{ }^{* *} \mathrm{p}<0.05,{ }^{*} \mathrm{p}<0.1$. Dependent variable is the annualized growth of the number of permanent, full-time employees between last fiscal year and 3 fiscal years before as defined in the text. $w k f_{i}$ is the firm-specific share of working capital that is financed externally; $w k f_{j}$ is the average share of working capital financing at the (4-digit) industry level; and $w \tilde{k} f_{j}$ is the average industry-wide share of working capital financing in financially unconstrained firms. Size is the initial number of permanent full-time employees and productivity is the initial sales per employee - both 3 fiscal years before. Foreign ownership, exporter and govt. ownership are dummy variables. Fixed effects for each industry-country-year cell are included in all regressions. 
Table 2: Access to finance and firm-level employment: differential impact within industry-countryyear cells.

\begin{tabular}{|c|c|c|c|c|c|c|}
\hline & (1) & (2) & (3) & (4) & (5) & (6) \\
\hline & \multicolumn{6}{|c|}{ Dependent variable: Annual employment growth (\%) } \\
\hline & high lc/rev & low lc/rev. & high lc/wc & low lc/wc & small firms & large firms \\
\hline \multirow{2}{*}{$\overline{D f c}$} & $-1.159^{* *}$ & -0.355 & -0.687 & -0.580 & $-0.716^{*}$ & $-2.541^{* * *}$ \\
\hline & $(0.473)$ & $(0.505)$ & $(0.620)$ & $(0.661)$ & $(0.380)$ & $(0.766)$ \\
\hline \multirow{2}{*}{$D f c \times w \tilde{k} f_{j}$} & $-2.489^{*}$ & -1.406 & $-3.784^{* *}$ & -1.162 & $-2.356^{* *}$ & 2.831 \\
\hline & $(1.401)$ & $(1.479)$ & $(1.792)$ & $(1.829)$ & $(1.156)$ & $(2.114)$ \\
\hline \multirow[t]{2}{*}{ age } & $-0.071^{* * *}$ & $-0.066^{* * *}$ & $-0.064^{* * *}$ & $-0.076^{* * *}$ & $-0.080^{* * *}$ & $-0.043^{* * *}$ \\
\hline & $(0.007)$ & $(0.007)$ & $(0.009)$ & $(0.008)$ & $(0.006)$ & $(0.007)$ \\
\hline \multirow[t]{2}{*}{$\log$ size } & $-3.663^{* * *}$ & $-2.774^{* * *}$ & $-3.888^{* * *}$ & $-2.588^{* * *}$ & $-9.306^{* * *}$ & $-5.405^{* * *}$ \\
\hline & $(0.096)$ & $(0.089)$ & $(0.121)$ & $(0.103)$ & $(0.200)$ & $(0.248)$ \\
\hline \multirow[t]{2}{*}{$\log$ (Productivity) } & $1.522^{* * *}$ & $1.507^{* * *}$ & $1.609^{* * *}$ & $1.717^{* * *}$ & $0.940^{* * *}$ & $1.088^{* * *}$ \\
\hline & $(0.077)$ & $(0.070)$ & $(0.091)$ & $(0.088)$ & $(0.088)$ & $(0.114)$ \\
\hline \multirow[t]{2}{*}{ Foreign ownership } & $1.894^{* * *}$ & $0.770^{* *}$ & $1.499^{* * *}$ & 0.303 & $0.672^{*}$ & $0.646^{*}$ \\
\hline & $(0.420)$ & $(0.382)$ & $(0.529)$ & $(0.462)$ & $(0.402)$ & $(0.383)$ \\
\hline \multirow[t]{2}{*}{ Exporter } & $3.761^{* * *}$ & $2.751^{* * *}$ & $4.671^{* * *}$ & $2.936^{* * *}$ & $2.605^{* * *}$ & $1.834^{* * *}$ \\
\hline & $(0.326)$ & $(0.292)$ & $(0.394)$ & $(0.317)$ & $(0.302)$ & $(0.287)$ \\
\hline \multirow[t]{2}{*}{ Govt. ownership } & $2.886^{* * *}$ & $2.001^{* *}$ & $3.850^{* * *}$ & 1.250 & $3.345^{* * *}$ & -0.802 \\
\hline & $(1.024)$ & $(0.947)$ & $(1.326)$ & (1.193) & $(0.899)$ & $(0.958)$ \\
\hline \multirow[t]{2}{*}{ Constant } & $-3.187^{* * *}$ & $-6.442^{* * *}$ & $-3.834^{* * *}$ & $-9.404^{* * *}$ & $15.928^{* * *}$ & $17.223^{* * *}$ \\
\hline & $(1.028)$ & $(1.018)$ & $(1.237)$ & $(1.271)$ & $(1.325)$ & $(1.814)$ \\
\hline Observations & 28,914 & 28,872 & 17,646 & 18,380 & 43,737 & 19,074 \\
\hline R-squared & 0.091 & 0.071 & 0.106 & 0.078 & 0.195 & 0.141 \\
\hline Number of panel & 7,167 & 7,124 & 4,493 & 4,258 & 8,582 & 5,624 \\
\hline
\end{tabular}

Note: Robust standard errors in parentheses are clustered at the $j c t$ level, ${ }^{* * *} \mathrm{p}<0.01,{ }^{* *} \mathrm{p}<0.05,{ }^{*} \mathrm{p}<0.1$. Dependent variable is the annualized growth of the number of permanent, full-time employees between last fiscal year and 3 fiscal years before as defined in the text. $w \tilde{k} f_{j}$ is the average industry-wide share of working capital financing in financially unconstrained firms. Size is the initial number of permanent full-time employees and productivity is the initial sales per employee - both 3 fiscal years before. Foreign ownership, exporter and govt. ownership are dummy variables. Fixed effects for each industry-country-year cell are included in all regressions. Column (1) and (2) split the sample into firms with high and low share of labor costs (salaries and benefits) in revenues. Column (3) and (4) splits the sample into high and low labor costs in working capital (approximated by the sum of variable expenses and inventories). Column (5) considers small firms and column (6) large firms (below and above 50 employees). 
Table 3: Access to finance and ex-post productivity: differential impact within industry-countryyear cells.

\begin{tabular}{|c|c|c|c|c|c|}
\hline & (1) & $(2)$ & (3) & (4) & (5) \\
\hline & \multicolumn{5}{|c|}{ Dependent variable: sales/worker } \\
\hline & all & all & small firms & high lc/wc & high lc/rev \\
\hline$D f c$ & -0.014 & -0.005 & 0.002 & -0.033 & 0.005 \\
\hline & $(0.010)$ & $(0.014)$ & $(0.016)$ & $(0.026)$ & $(0.026)$ \\
\hline$D f c \times w k f_{i}$ & $\begin{array}{l}-0.009 \\
(0.020)\end{array}$ & & & & \\
\hline$D f c \times w \tilde{k} f_{j}$ & & $\begin{array}{l}-0.031 \\
(0.042)\end{array}$ & $\begin{array}{l}-0.048 \\
(0.051)\end{array}$ & $\begin{array}{c}0.009 \\
(0.075)\end{array}$ & $\begin{array}{l}-0.068 \\
(0.077)\end{array}$ \\
\hline age & $\begin{array}{l}-0.000 \\
(0.000)\end{array}$ & $\begin{array}{l}-0.000 \\
(0.000)\end{array}$ & $\begin{array}{l}-0.001^{*} \\
(0.000)\end{array}$ & $\begin{array}{c}0.001 \\
(0.000)\end{array}$ & $\begin{array}{c}-0.000 \\
(0.000)\end{array}$ \\
\hline $\log$ size & $\begin{array}{c}0.053^{* * *} \\
(0.003)\end{array}$ & $\begin{array}{c}0.054^{* * *} \\
(0.003)\end{array}$ & $\begin{array}{c}0.121^{* * *} \\
(0.006)\end{array}$ & $\begin{array}{c}0.061^{* * *} \\
(0.006)\end{array}$ & $\begin{array}{c}0.042^{* * *} \\
(0.004)\end{array}$ \\
\hline $\log$ (Productivity) & $\begin{array}{c}0.810^{* * *} \\
(0.005)\end{array}$ & $\begin{array}{c}0.812^{* * *} \\
(0.005)\end{array}$ & $\begin{array}{c}0.806^{* * *} \\
(0.006)\end{array}$ & $\begin{array}{c}0.714^{* * *} \\
(0.012)\end{array}$ & $\begin{array}{c}0.772^{* * *} \\
(0.009)\end{array}$ \\
\hline Foreign ownership & $\begin{array}{c}0.083^{* * *} \\
(0.012)\end{array}$ & $\begin{array}{c}0.083^{* * *} \\
(0.012)\end{array}$ & $\begin{array}{c}0.085^{* * *} \\
(0.018)\end{array}$ & $\begin{array}{c}0.116^{* * *} \\
(0.025)\end{array}$ & $\begin{array}{c}0.097^{* * *} \\
(0.018)\end{array}$ \\
\hline Exporter & $\begin{array}{c}0.037^{* * *} \\
(0.009)\end{array}$ & $\begin{array}{c}0.038^{* * *} \\
(0.009)\end{array}$ & $\begin{array}{c}0.040^{* * *} \\
(0.013)\end{array}$ & $\begin{array}{l}0.037^{* *} \\
(0.018)\end{array}$ & $\begin{array}{c}0.056^{* * *} \\
(0.014)\end{array}$ \\
\hline Govt. ownership & $\begin{array}{l}-0.064^{*} \\
(0.034)\end{array}$ & $\begin{array}{l}-0.055 \\
(0.034)\end{array}$ & $\begin{array}{c}-0.125^{* *} \\
(0.057)\end{array}$ & $\begin{array}{c}-0.074 \\
(0.061)\end{array}$ & $\begin{array}{c}-0.032 \\
(0.047)\end{array}$ \\
\hline$w k f_{i}$ & $\begin{array}{c}0.000^{* * *} \\
(0.000)\end{array}$ & & & & \\
\hline Constant & $\begin{array}{c}2.478^{* * *} \\
(0.069)\end{array}$ & $\begin{array}{c}2.454^{* * *} \\
(0.069)\end{array}$ & $\begin{array}{c}2.407^{* * *} \\
(0.076)\end{array}$ & $\begin{array}{c}3.625^{* * *} \\
(0.148)\end{array}$ & $\begin{array}{c}3.219^{* * *} \\
(0.122)\end{array}$ \\
\hline Observations & 60,956 & 60,151 & 41,804 & 17,109 & 28,117 \\
\hline R-squared & 0.739 & 0.740 & 0.723 & 0.624 & 0.712 \\
\hline Number of panel & 10,998 & 9,841 & 8,371 & 4,375 & 6,984 \\
\hline
\end{tabular}

Note: Robust standard errors in parentheses are clustered at the $j c t$ level, ${ }^{* * *} \mathrm{p}<0.01,{ }^{* *} \mathrm{p}<0.05,{ }^{*} \mathrm{p}<0.1$. Dependent variable is the last fiscal year's total nominal sales divided by the total number of full-time permanent workers at the firm. $w \tilde{k} f_{j}$ is the average industry-wide share of working capital financing in financially unconstrained firms. Size is the initial number of permanent full-time employees and productivity is the initial sales per employee - both 3 fiscal years before. Foreign ownership, exporter and govt. ownership are dummy variables. Fixed effects for each industry-country-year cell are included in all regressions. The definition of high labor share in revenue and working capital, and that of small firms is as in Table 2 
Table 4: Within-firm panel regression using BEEPS data

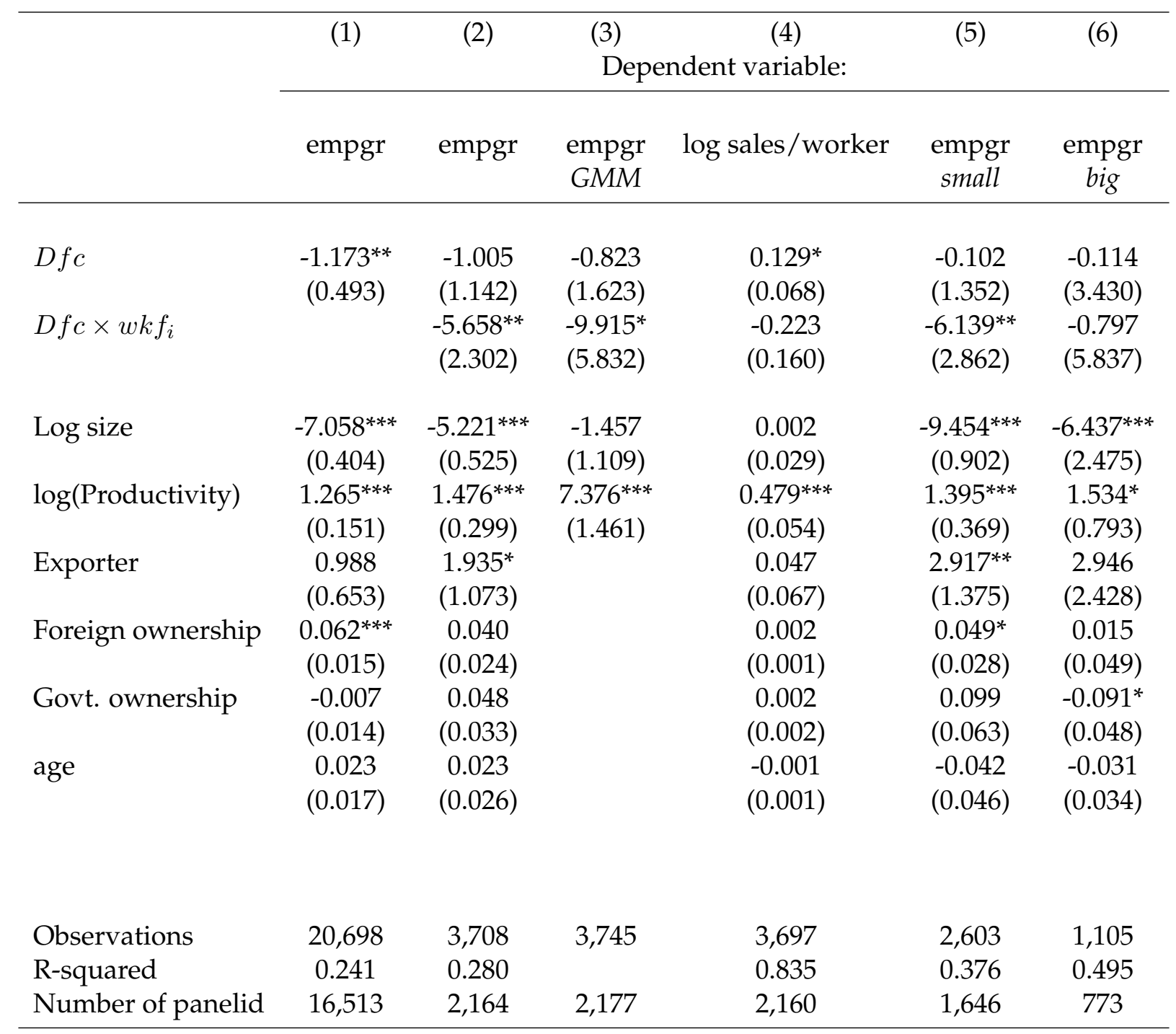

Note: Robust standard errors in parentheses are clustered at the firm level, ${ }^{* * *} \mathrm{p}<0.01,{ }^{* *} \mathrm{p}<0.05,{ }^{*} \mathrm{p}<0.1$. All regressions include country-year, industry-year as well as firm fixed effects. 
Table 5: Working capital versus fixed capital financing channel.

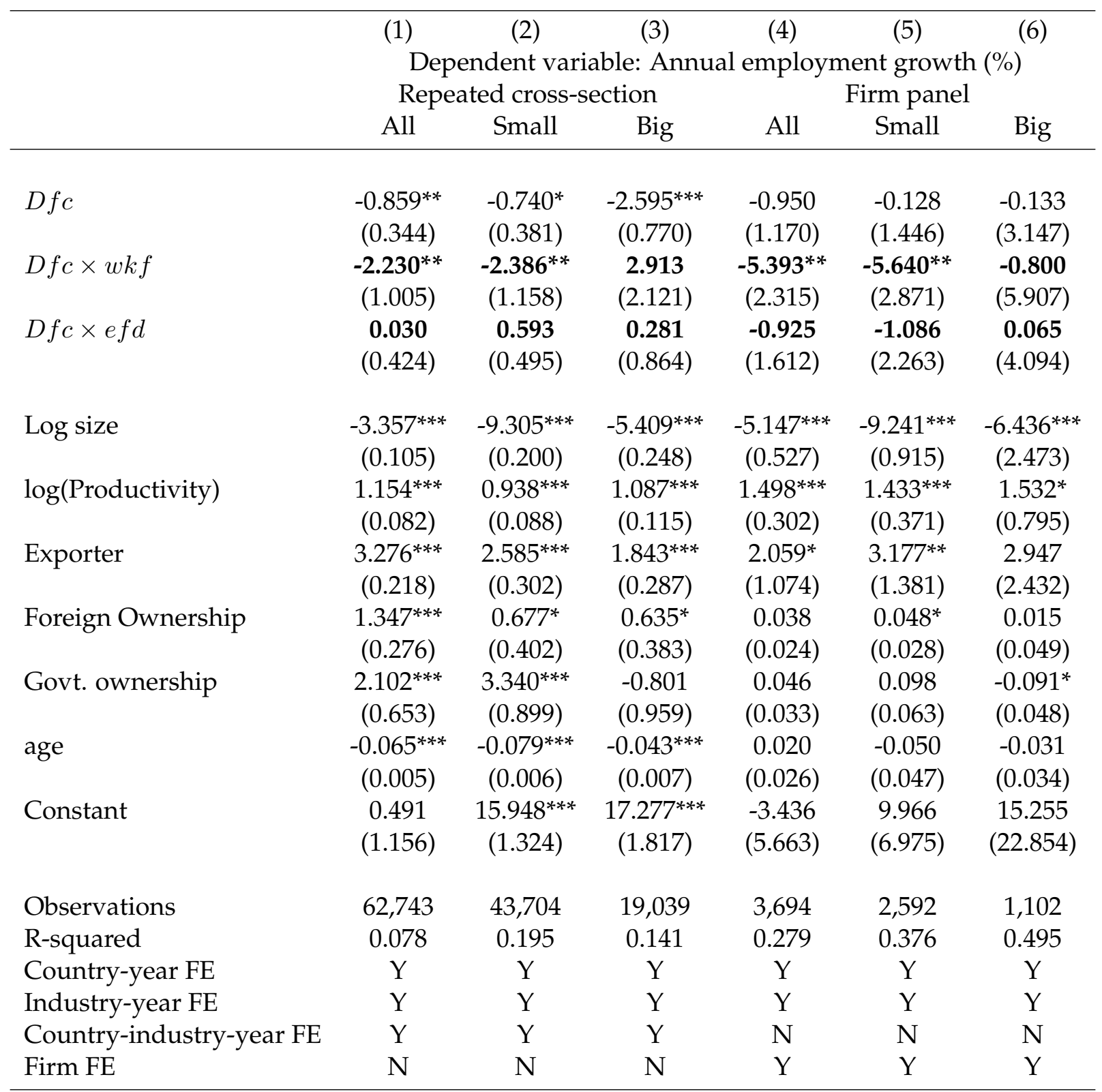

Note: Robust standard errors in parentheses are clustered at the country-industry level (column 1-3) or firm level (column 4-6), ${ }^{* * *} \mathrm{p}<0.01,{ }^{* *} \mathrm{p}<0.05,{ }^{*} \mathrm{p}<0.1$. efd refers to the industry-specific external financial dependence as developed by Rajan and Zingales (1998) and constructed as described in the main text. 
Table 6: Difference-in-difference estimation.

\begin{tabular}{|c|c|c|c|}
\hline & $(1)$ & (2) & (3) \\
\hline & all & small & large \\
\hline CreditIndex $x_{c, t} \times w k f_{j}$ & $\begin{array}{l}-0.006 \\
(0.026)\end{array}$ & $\begin{array}{l}0.010^{* *} \\
(0.005)\end{array}$ & $\begin{array}{c}-0.006 \\
(0.074)\end{array}$ \\
\hline Country-year FE & yes & yes & yes \\
\hline Industry-year FE & yes & yes & yes \\
\hline Observations & 62,152 & 41,577 & 20,575 \\
\hline R-squared & 0.022 & 0.041 & 0.059 \\
\hline
\end{tabular}

Note: Robust standard errors in parentheses are clustered at the indsutry-country-year level, ${ }^{* * *} \mathrm{p}<0.01,{ }^{* *} \mathrm{p}<0.05,{ }^{*}$ $\mathrm{p}<0.1$. All regressions include country-year, industry-year fixed effects. Credit Index refers to the structural indicator of the ease of getting credit based on collateral and bankruptcy laws constructed by the Doing Business report of the World Bank. The industry-level share of working capital financing need $w k f_{j}$ is aggregated over all firms and all years. Column (2) limits the sample to all firms with 50 full-time permanent employees or less, column (3) on firms with more than 50 employees. 


\section{Appendices}

\section{Appendix A: Proofs}

Proof of Proposition 1: To see when the borrowing constraint binds, solving the FOC (3) for $L$ yields

$$
L=\left[\frac{(1+\eta \lambda) \alpha A}{[(1+\eta) \theta R+(1+\eta \lambda)(1-\theta)] w}\right]^{\frac{1}{1-\alpha}} .
$$

Plugging the expression for $L$ into the FOC (4), we can then derive an expression for the multiplier $\eta$ :

$$
\eta=-\frac{(1-\alpha / \lambda) R \theta+(1-\alpha)(1-\theta)}{(1-\alpha)[R \theta+\lambda(1-\theta)]}
$$

$\eta>0$ iff $(1-\alpha / \lambda) R \theta+(1-\alpha)(1-\theta)<0$, which is equivalent to $\lambda<\hat{\lambda}=\frac{\alpha R \theta}{R \theta+(1-\alpha)(1-\theta)}$. That is, when $\lambda<\hat{\lambda}, \eta>0$ and the borrowing constraint is always binding. In this case, solving equation (4) yields the expression for $\hat{L}$. When $\lambda \geq \hat{\lambda}, \eta \leq 0$ and the borrowing constraint does not bind. In this case, solving equation (3) yields the expression for $L^{*}$.

Derivation of (7): Using the result in (5), differentiating $\ln \hat{L}$ w.r.t. $\lambda$ yields

$$
\frac{d \ln \hat{L}}{d \lambda}=\frac{R \theta}{(1-\alpha) \lambda[R \theta+\lambda(1-\theta)]}>0 .
$$

From this, it is straightforward to see that the results in (7) hold.

Proof of Proposition 2: Same in the model with labor input only, we denote $\eta$ as the multiplier associated with the borrowing constraint. The optimization problem yields the following firstorder conditions:

$$
\begin{gathered}
\alpha A K^{\beta} L^{\alpha-1}=[\theta R+(1-\theta)] w-\eta\left[\lambda \alpha A K^{\beta} L^{\alpha-1}-\lambda(1-\theta) w-\theta R w\right], \\
\beta A K^{\beta-1} L^{\alpha}=[\theta R+(1-\theta)] p_{K}-\eta\left[\lambda \beta A K^{\beta-1} L^{\alpha}-\lambda(1-\theta) p_{K}-\theta R p_{K}\right], \\
\lambda\left[A K^{\beta} L^{\alpha}-(1-\theta)\left(w L+p_{K} K\right)\right]-\theta R\left(w L+p_{K} K\right) \geq 0 ; \text { equal if } \eta>0 .
\end{gathered}
$$


To see when the borrowing constraint binds, simplify the FOCs in ([18) and ([19), and then solve for $L$ and $K$ :

$$
L=\left[\frac{(1+\eta \lambda) \alpha A\left(\frac{\beta w}{\alpha p_{K}}\right)^{\beta}}{[(1+\eta) \theta R+(1+\eta \lambda)(1-\theta)] w}\right]^{\frac{1}{1-\alpha-\beta}}, \text { and } K=\frac{\beta w}{\alpha p_{K}} L
$$

Plugging the expression for $L$ and $K$ into the FOC (20), we can then derive an expression for the multiplier $\eta$ :

$$
\eta=-\frac{[1-(\alpha+\beta) / \lambda] R \theta+(1-\alpha-\beta)(1-\theta)}{(1-\alpha-\beta)[R \theta+\lambda(1-\theta)]}
$$

$\eta>0$ iff $[1-(\alpha+\beta) / \lambda] R \theta+(1-\alpha-\beta)(1-\theta)<0$, which is equivalent to $\lambda<\hat{\lambda}=\frac{(\alpha+\beta) R \theta}{R \theta+(1-\alpha-\beta)(1-\theta)}$.

Similar to the proof of Proposition 1 , when $\lambda<\hat{\lambda}, \eta>0$ and the borrowing constraint is always binding. In this case, solving equation (20) and using $K=\frac{\beta w}{\alpha p_{K}} L$, we can derive the expressions for $\hat{L}$ and $\hat{K}$. When $\lambda \geq \hat{\lambda}, \eta \leq 0$ and the borrowing constraint does not bind. FOCs (18) and (19) yields the expressions for $L^{*}$ and $K^{*}$.

Derivation of 11): Using the result in (9), differentiating $\ln \hat{L}$ w.r.t. $\lambda$ yields

$$
\frac{d \ln \hat{L}}{d \lambda}=\frac{R \theta}{(1-\alpha-\beta) \lambda[R \theta+\lambda(1-\theta)]} .
$$

From this, it is straightforward to see that the results in (11) hold.

Derivation of (12): Following simple algebra, all the derivative results can be derived directly from the above equation (21). 


\section{Appendix B: Appendix Tables}

Table B.1: List of survey countries and years.

\begin{tabular}{|l|l|l|}
\hline \multicolumn{1}{|c|}{ Country name } & Survey years & No. of firms surveyed \\
\hline Albania & 2007 & 132 \\
Albania & 2013 & 108 \\
Angola & 2006 & 141 \\
Angola & 2010 & 133 \\
Argentina & 2006 & 432 \\
Argentina & 2010 & 788 \\
Armenia & 2013 & 199 \\
Azerbaijan & 2013 & 115 \\
Bahamas & 2010 & 109 \\
Bangladesh & 2007 & 739 \\
Bangladesh & 2013 & 1307 \\
Barbados & 2010 & 104 \\
Belarus & 2013 & 210 \\
Belize & 2010 & 145 \\
Benin & 2009 & 92 \\
Bhutan & 2009 & 218 \\
Bhutan & 2015 & 215 \\
Bosnia and Herzegovina & 2013 & 275 \\
Bolivia & 2006 & 226 \\
Bolivia & 2010 & 151 \\
Botswana & 2006 & 82 \\
Botswana & 2010 & 196 \\
Brazil & 2009 & 970 \\
Bulgaria & 2013 \\
Bulgaria & 2007 & 865 \\
Burkina Faso & 2013 & 247 \\
Burundi & 2009 & 295 \\
Burundi & 2006 & 87 \\
Cameroon & 2014 & 132 \\
Cape Verde & 2009 & 313 \\
Chad & 2009 & 73 \\
Chile & 2009 & 110 \\
Chile & 2006 & 532 \\
China & 2010 & 848 \\
Colombia & 2012 & 2368 \\
Colombia & 492 \\
Costa Rica & 822 \\
Cote d'Ivoire & 328 \\
Croatia & 281 \\
Croatia & 2006 \\
Czech Republic & 2010 \\
\hline & 2097 ont on next page \\
\hline
\end{tabular}


Table B.1 - continued from previous page

\begin{tabular}{|l|l|l|}
\hline \multicolumn{1}{|c|}{ Country name } & Survey years & No. of firms surveyed \\
\hline Dibouti & 2013 & 51 \\
Dominica & 2010 & 139 \\
Dominican Republic & 2010 & 262 \\
DRC & 2006 & 120 \\
DRC & 2010 & 216 \\
DRC & 2013 & 353 \\
Ecuador & 2006 & 235 \\
Ecuador & 2010 & 284 \\
Egypt & 2013 & 2009 \\
El Salvador & 2006 & 339 \\
El Salvador & 2010 & 252 \\
Eritrea & 2009 & 86 \\
Estonia & 2013 & 203 \\
Ethiopia & 2011 & 310 \\
Fiji & 2009 & 67 \\
Macedonia (Fyrom) & 2013 & 317 \\
Gambia & 2006 & 25 \\
Georgia & 2013 & 183 \\
Ghana & 2007 & 261 \\
Ghana & 2013 & 452 \\
Grenada & 2010 & 127 \\
Guatemala & 2006 & 277 \\
Guatemala & 2010 & 374 \\
Guinea & 2006 & 107 \\
Guinea Bissau & 2006 & 36 \\
Guyana & 2010 & 118 \\
Honduras & 2006 & 210 \\
Honduras & 2010 & 211 \\
Hungary & 2013 & 121 \\
India & 2014 & 8101 \\
Indonesia & 2009 & 1089 \\
Iraq & 2011 & 679 \\
Israel & 2013 & 391 \\
Jamaica & 2010 & 222 \\
Jordan & 2013 & 446 \\
Kazakhstan & 2013 & 282 \\
Kenya & 2007 & 387 \\
Kenya & 2013 & 583 \\
Kosovo & 2013 & 148 \\
Kyrgyzstan & 2013 & 182 \\
Laos & 2009 & 350 \\
Laos & 2012 & 176 \\
Latvia & 2013 & 156 \\
Lebanon & 2013 & 381 \\
Lithuania & 2013 & 159 \\
\hline & & Continued on next page \\
\hline
\end{tabular}


Table B.1 - continued from previous page

\begin{tabular}{|l|l|l|}
\hline \multicolumn{1}{|c|}{ Country name } & Survey years & No. of firms surveyed \\
\hline Madagascar & 2009 & 290 \\
Malawi & 2009 & 97 \\
Malawi & 2014 & 261 \\
Mali & 2007 & 256 \\
Mali & 2010 & 93 \\
Mauritania & 2006 & 70 \\
Mauritania & 2014 & 83 \\
Mauritius & 2009 & 276 \\
Mexico & 2006 & 830 \\
Mexico & 2010 & 1197 \\
Micronesia, Fed. Sts. & 2009 & 47 \\
Moldova & 2013 & 250 \\
Mongolia & 2013 & 269 \\
Montenegro & 2013 & 89 \\
Morocco & 2013 & 307 \\
Mozambique & 2007 & 300 \\
Myanmar & 2014 & 469 \\
Namibia & 2006 & 73 \\
Namibia & 2014 & 214 \\
Nepal & 2009 & 299 \\
Nepal & 2013 & 450 \\
Nicaragua & 2006 & 277 \\
Nicaragua & 2010 & 243 \\
Niger & 2009 & 74 \\
Nigeria & 2007 & 838 \\
Nigeria & 2014 & 1408 \\
Pakistan & 2013 & 489 \\
Panama & 2006 & 134 \\
Panama & 2010 & 146 \\
Paraguay & 2006 & 201 \\
Paraguay & 2010 & 250 \\
Peru & 2006 & 299 \\
Peru & 2010 & 804 \\
Philippines & 2009 & 922 \\
Poland & 2013 & 262 \\
Romania & 2013 & 410 \\
Russia & 2012 & 2272 \\
Rwanda & 2006 & 45 \\
Rwanda & 2011 & 156 \\
Samoa & 2009 & 51 \\
Senegal & 2007 & 230 \\
Senegal & 2014 & 326 \\
Serbia & 2013 & 274 \\
Slovakia & 2013 & 115 \\
Slovenia & 2013 & 203 \\
\hline & & Continued on next page \\
\hline
\end{tabular}


Table B.1 - continued from previous page

\begin{tabular}{|l|l|l|}
\hline \multicolumn{1}{|c|}{ Country name } & Survey years & No. of firms surveyed \\
\hline South Africa & 2007 & 592 \\
Sri Lanka & 2011 & 467 \\
Suriname & 2010 & 149 \\
Swaziland & 2006 & 51 \\
Sweden & 2014 & 481 \\
Tajikistan & 2013 & 170 \\
Tanzania & 2006 & 237 \\
Tanzania & 2013 & 259 \\
Timor-Leste & 2009 & 72 \\
Togo & 2009 & 76 \\
Tonga & 2009 & 110 \\
Trinidad and Tobago & 2010 & 284 \\
Tunisia & 2013 & 553 \\
Turkey & 2013 & 632 \\
Uganda & 2006 & 269 \\
Uganda & 2013 & 329 \\
Ukraine & 2013 & 319 \\
Uruguay & 2006 & 194 \\
Uruguay & 2010 & 381 \\
Uzbekistan & 2013 & 234 \\
Vanuatu & 2009 & 75 \\
Venezuela & 2010 & 135 \\
Vietnam & 2009 & 828 \\
Yemen & 2010 & 255 \\
Yemen & 2013 & 251 \\
Zambia & 2007 & 249 \\
Zambia & 2013 & 518 \\
\hline \hline
\end{tabular}


Table B.2: Country and years in BEEPS sample

\begin{tabular}{lcl}
\multicolumn{1}{c}{ Country } & Unique firms & Survey years \\
Albania & 177 & $2002,2005,2009,2013$ \\
Belarus & 453 & $2002,2005,2008,2013$ \\
Georgia & 563 & $2002,2005,2008,2013$ \\
Tajikistan & 518 & $2002,2005,2008,2013$ \\
Turkey & 625 & 2008,2013 \\
Ukraine & 1139 & $2005,2008,2013$ \\
Uzbekistan & 697 & $2002,2005,2008,2013$ \\
Russia & 1300 & $2002,2005,2009$ \\
Poland & 625 & $2002,2005,2009,2013$ \\
Romania & 675 & $2002,2005,2009,2013$ \\
Serbia & 677 & $2002,2005,2009,2013$ \\
Kazakhstan & 787 & $2002,2005,2009,2013$ \\
Moldova & 660 & $2002,2005,2009,2013$ \\
Bosnia and Herzegovina & 535 & $2005,2009,2013$ \\
Azerbaijan & 583 & 2002,2013 \\
Fyr Macedonia & 820 & $2002,2005,2009,2013$ \\
Armenia & 523 & $2002,2005,2009,2013$ \\
Kyrgyz Republic & 416 & $2002,2005,2009,2013$ \\
Mongolia & 338 & 2009,2013 \\
Estonia & 523 & $2002,2005,2009,2013$ \\
Kosovo & 145 & 2009,2013 \\
Czech Republic & 385 & $2002,2005,2009,2013$ \\
Hungary & 579 & $2002,2005,2009,2013$ \\
Latvia & 469 & $2002,2005,2009,2013$ \\
Lithuania & 458 & $2002,2005,2009,2013$ \\
Slovak Republic & 353 & $2002,2005,2009,2013$ \\
Slovenia & 532 & $2002,2005,2009,2013$ \\
Bulgaria & 534 & $2002,2005,2007,2009,2013$ \\
Croatia & 281 & $2002,2005,2009,2013$ \\
Montenegro & 143 & 2009,2013 \\
Total & 16,513 & \\
& & \\
& &
\end{tabular}

